\title{
An Agency Theoretical Approach To Corporate Board Diversity
}

\author{
SANDEEP GOPALAN* \\ KATHERINE WATSON**
}

\section{TABLE OF CONTENTS}

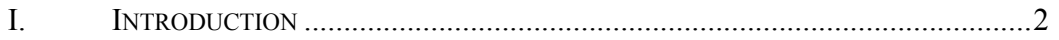

II. THE CASE FOR GENDER DIVERSITY …................................................... 7

A. Diversity and Firm Performance ….......................................... 7

B. Talent Pool ............................................................................ 14

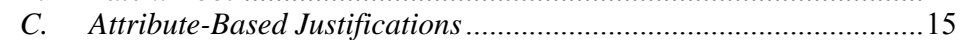

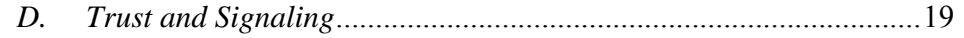

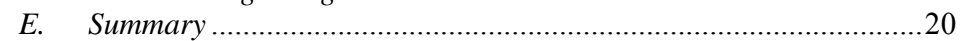

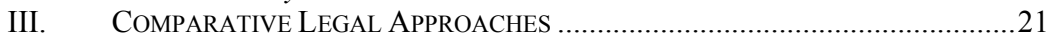

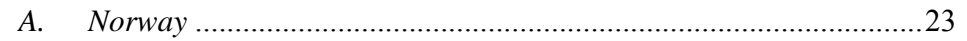

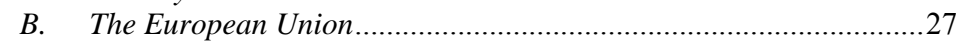

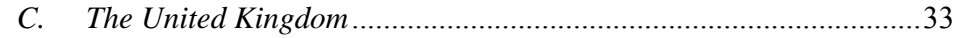

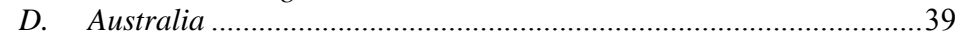

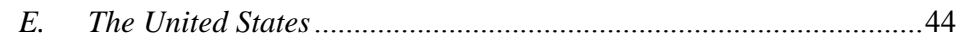

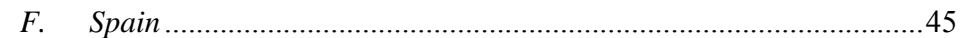

G. Other Countries ......................................................................... 48

H. Countries with Quotas for State-Owned Enterprises .......................53

I. Other Initiatives .........................................................................56

IV. A BINDING SHAREHOLDER VOTE ON DIVERSITY ….................................58

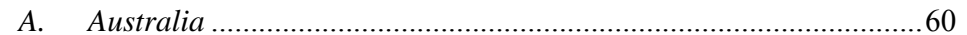

* $\quad$ (C) 2015 Sandeep Gopalan. Dean and Professor of Law, University of Newcastle Law School. I would like to express my gratitude to Terrie Troxel, Jack Tatom, and the Networks Financial Institute at Indiana State University for providing valuable support in writing this paper. I am also grateful to Brandon Smith, Jacqueline Travers, Gwendolyn Holdgreiwe, Bronson Smith, and the staff of the San Diego Law Review for their excellent editorial work.

** (C) 2015 Katherine Watson. University of Newcastle Law School. 

B. The Dodd-Frank Say on Pay.... .62
C. Merits of a Binding Vote on Diversity

\section{INTRODUCTION}

Diversity is the new frontier in corporate governance literature. There is widespread attention to the topic from legislators, regulatory agencies, activists, and the media lamenting the low levels of women's representation on corporate boards in countries with both a legal commitment to gender equality and a strong record of equality at a societal level. Women hold less than $17 \%$ of the board positions in corporate America, and unsurprisingly, hard questions for this inequality of representation are being asked in a milieu where corporations are acknowledged to have a greater purpose than short-term profit maximization. ${ }^{1}$ As the Supreme Court said in Burwell v. Hobby Lobby Stores, Inc.,

[although] a central objective of for-profit corporations is to make money, modern corporate law does not require for-profit corporations to pursue profit at the expense of everything else, and many do not do so. For-profit corporations, with ownership approval, support a wide variety of charitable causes, and it is not at all uncommon for such corporations to further humanitarian and other altruistic objectives. $^{2}$

Corporations are paying attention, although it is unclear whether change is driven by the threat of legislatively mandated quotas or the realization that increasing the number of women on boards is good for the bottom line. ${ }^{3}$ For instance, gender diversity on United Kingdom corporate boards has increased at a dramatic rate following the publication of Lord Davies' report $^{4}$ and sustained media and political attention to the topic. ${ }^{5}$ BoardWatch reports that as of December 2014, 23\% of directors of FTSE 100 companies are women, with the share of nonexecutive directors being

1. Quick Take: Women on Boards, CATALYsT (Mar. 3, 2014), http://www. catalyst.org/knowledge/women-boards.

2. $\quad$ Burwell v. Hobby Lobby Stores, Inc., 134 S. Ct. 2751, 2771 (2014).

3. Claer Barrett, Gender Quotas Feel Coercive but Appear To Work, Fin. TIMES (May 15, 2014, 12:29 AM), http://www.ft.com/intl/cms/s/0/aef9d9c4-d521-11e3-918700144feabdc0.html\#axzz3HebMIE3d.

4. See LORD DAVIES OF ABERSOCH, WOMEN ON BoARdS (2011), https://www. gov.uk/government/uploads/system/uploads/attachment data/file/31480/11-745-womenon-boards.pdf.

5. See generally THE 30\% CLUB, http://www.30percentclub.org (last visited Mar. 30,2015 ) (reporting the progress of increased gender diversity in boardrooms in the United Kingdom). 
$28.2 \%{ }^{6}$ Whereas there were twenty-one boards with no women directors in February 2011, there is not even one such company today. ${ }^{7}$ Across the FTSE $250,17.7 \%$ of directors are women, with over $20 \%$ being nonexecutives. ${ }^{8}$ This group went from $52.4 \%$ all-male boards to $9.6 \% .{ }^{9}$ Although the rhetoric in that country has consistently been around the need to access the female talent pool and how valuable it is for businesses to have more women on their boards, the pace of change since 2010 might suggest an underlying fear about mandatory quotas. ${ }^{10}$ This is likely given the looming threat of legislation at the European Union level, ${ }^{11}$ pervasive popular distrust in big business, and political interest in the topic domestically. ${ }^{12}$ To be sure, legislatively mandated quotas have dramatically altered the proportion of women on boards in a number of European countries, most notably Norway and France. ${ }^{13}$ The European Union has proposed a directive modelled, if not in letter then in spirit, on the Norwegian experience. ${ }^{14}$

6. BoardWatch, PROF. BOARDS F. (Dec. 2014), http://boardsforum.co.uk/board watch.html. Only $12.5 \%$ of the directors of FTSE 100 companies were women in early 2011. Id.

7. Id.

8. Id.

9. Id.

10. See Erika Watson, Quotas Aren't the Best Way To Get More Women into Boardrooms, GUARDIAN (Mar. 18, 2012, 9:45 AM), http://www.theguardian.com/ commentisfree/2012/mar/18/quotas-women-boardroom-equality.

11. See EuROPEAN COMM'N, COMMUNICATION FROM THE COMMISSION TO THE European Parliament, the Council, the European ECONOMiC and Social CommitTee, and the Committee of the Regions: Commission Work Programme 2012, at 2-3, 11 (2011); European Comm'n, Green Paper: The EU Corporate Governance FRAMEWORK 7 (2011), http://ec.europa.eu/internal_market/company/docs/modern/com2011164_en.pdf; European COMM'N, STRATEgy for EQuality Between WOMEN AND MeN $201 \overline{0}-2015$, at 20 (2011), http://ec.europa.eu/justice/gender-equality/files/strategy_equality _women_men_en.pdf; EUROPEAN COMM'N, WOMEN IN ECONOMIC DECISION-MĀKING IN THE EU: ProGress RePORT 5 (2012) [hereinafter EuROPEAN COMM'N, WOMEN IN DECISION-MAKING], http://ec.europa.eu/justice/gender-equality/files/women-on-boards_ en.pdf; Press Release, European Comm'n, European Union Justice Commissioner Reding Challenges Business Leaders To Increase Women's Presence on Corporate Boards with "Women on the Board Pledge for Europe" (Mar. 1, 2011) [hereinafter Press Release, Women on the Board Pledge], http://europa.eu/rapid/press-release_MEMO-11-124_en.htm.

12. Leo Cendrowicz, Can Mandatory Quotas Bring Gender Equality to Europe's Boardrooms? TIME (Mar. 8, 2012), http://content.time.com/time/world/article/0,8599, 2108607,00.html.

13. See Waving a Big Stick, ECONOMIST (Mar. 10, 2012), http://www.economist. com/node/21549953.

14. See Cendrowicz, supra note 12 . 
On the contrary, in the United States, the Securities and Exchange Commission (SEC) has abjured quotas and has only required diversity disclosure since $2010 .{ }^{15}$ Remarkably, the consultation process prior to the adoption of the SEC rule witnessed responses from market actors representing over $\$ 3$ trillion in assets, and $90 \%$ of the letters indicated dissatisfaction with the status quo and expressed support for disclosure of diversity information. ${ }^{16}$ In the years since, a senior SEC official has confessed that the disclosure regime is not working effectively, ${ }^{17}$ noting that

many ... companies provided only abstract disclosure ... a brief statement indicating that diversity was something considered as part of an informal policy. [There was no] discussion of any concrete steps taken to give real meaning to its efforts to create a diverse board.... [T] hese companies fail to provide investors with useful information, and it deprives investors of information they have demanded. 18

Recent academic work confirms that companies are not complying with the requirements of the rule and that change has been slow. ${ }^{19}$ On the other side of the globe, Australia offers an interesting case study. In the early stages of legislative intervention in other countries, Australia was cited as a positive example for a nonquota solution. ${ }^{20}$ However, recent evidence indicates that women's representation on corporate boards has not kept pace and the existing legal scheme is neither precisely tailored to achieving its stated objectives nor enforced as written. ${ }^{21}$

Cross-country studies show that legal mandates have been more potent than voluntary initiatives. ${ }^{22}$ For instance, France has witnessed an increase in female board representation in its top 200 companies from $7.2 \%$ ten years ago to about $30 \%$ today thanks to a quota law passed in

15. See Luis A. Aguilar, Comm'r, U.S. Sec. \& Exch. Comm'n, Speech at the Center for Transatlantic Relations Conference on Global Perspectives on Women in the Boardroom: Diversity in the Boardroom Is Important and, Unfortunately, Still Rare (Sept. 16, 2010), http://www.sec.gov/news/speech/2010/spch091610laa.htm.

16. Id.

17. Luis A. Aguilar, Comm'r, U.S. Sec. \& Exch. Comm'n, Speech at the Agenda Luncheon Program: Board Diversity: Why It Matters and How To Improve It (Nov. 4, 2010), http://www.sec.gov/news/speech/2010/spch110410laa.htm.

18. Id. For a similar comment in the Australian context, see BlACKRock Investment Mgmt. (Austl.) Ltd., Glacial Change in Diversity at ASX 200 COMPANIES: CAN CORPORATE AUSTRALIA ESCAPE THE IMPOSITION OF DivERSiTy QUOTAS? $2-3(2012)$.

19. See Tamara S. Smallman, Note, The Glass Boardroom: The SEC's Role in Cracking the Door Open so Women May Enter, 2013 ColuM. Bus. L. REV. 801, 804.

20. See LORD DAVIES OF ABERSOCH, supra note 4, at 13, 27.

21. See BlackRock Investment Mgmt. (Austl.) Ltd., supra note 18, at 2-3, 5.

22. See EUROPEAN COMM'N, WOMEN IN DECISION-MAKING, supra note 11, at 13. 
$2010 .^{23}$ The corresponding data for Italy - which passed a quota law in 2011 - is even more incredible, rising from $1.8 \%$ in 2004 to almost $26 \%$ at present. ${ }^{24}$ In contrast, the Australian rate of change has been described as "glacial.". Just $19.3 \%$ of the directors of Australian companies listed on the Australian Securities Exchange (ASX) 200 are women, and thirtyfive ASX 200 companies do not have any women on the board. ${ }^{26}$ The figure for ASX 201-300 companies for 2012 was a mere $7.6 \%{ }^{27}$ Four years since the adoption of the ASX Guidelines, a study conducted by KPMG for the ASX showed that "it is evident that many organisations still have a long way to go in terms of establishing clear and measurable objectives and working towards improving the number of women." 28 The United States presents a similar picture with just $16.9 \%$ of board positions being held by women in 2014. ${ }^{29}$ The ten-year rate of growth in women's representation in the United States is a mere 5\%-lagging behind corresponding figures in Europe by over 8\%. ${ }^{30}$

This evidence indicates that the existing regimes in the United States and Australia are ill suited to their objectives and are unlikely to yield a significant upward change in women's representation on boards within a reasonable timeframe. Therefore, we posit a normative model for increasing women's representation on corporate boards based upon a comparative study of several jurisdictions built upon shareholder empowerment. We argue that the evidence indicates that voluntary models such as those pursued by the United States and Australia are designed to fail because of conceptual overdetermination, misalignment of incentives, and prohibitive enforcement costs. The sole example of successful voluntary action - the United Kingdom - can be explained by the looming shadow of mandatory

23. Hugh Carnegy, Europe Leads the Way in the Number of Women on Top Company Boards, FIN. TIMES (June 5, 2014, 11:00 AM), http://www.ft.com/cms/s/0/ 6389d9e0-ebf5-11e3-ab1b00144feabdc0.html\#axzz35p4vHJCv.

24. Id.

25. BlackRock InVestment Mgmt. (Austl.) Ltd., supra note 18, at 2.

26. Statistics, AUSTL. INST. COMPANY DIRECTORS, http://www.companydirectors.com.au/ Director-Resource-Centre/Governance-and-Director-Issues/Board-Diversity/Statistics (last visited Mar. 30, 2015).

27. See Boardroom Diversity Index 2013, WOMEN ON BOARDS, http://www.women onboards.org.au/pubs/bdi/2013/index.htm (last visited Mar. 30, 2015).

28. KPMG, ASX Corporate Governance Council Principles and RECOMMENDATIONS ON DIVERSITY 4 (2014), http://www.asx.com.au/documents/asxcompliance/kpmg-report-diversity-2014.pdf.

29. Quick Take: Women on Boards, supra note 1.

30. See Carnegy, supra note 23. 
quotas. Amidst the pervasive lack of trust following the financial crisis of 2008 in the United Kingdom, the deep suspicion of European Union legislation mandating quotas seems to have pushed United Kingdom companies to advance the diversity agenda as a means of preempting unwelcome regulatory attention. ${ }^{31}$

Bereft of such a threat, existing approaches in the United States and Australia are not likely to yield similar numerical results or corporate governance advantages from a compliance focused model. Despite this reality, we do not propose mandatory quotas - at least not in corporate governance law - because gender quotas are ill suited to the core goals of that instrument. Instead, we employ agency theory and argue thatcongruent with the stated goals of corporate governance law to facilitate more effective monitoring of management by shareholders - the SEC diversity disclosure rules should make way for a law mandating a binding shareholder vote on diversity. This vote should be held annually and give shareholders an opportunity to vote on whether the company ought to consider diversity in board appointments, adopt a diversity policy, specify diversity targets, and enforce such targets by internal mechanisms such as links to executive pay. If - as the arguments advanced by proponents claim - board diversity is valuable to shareholders, such resolutions will be adopted and women's representation will increase. Moreover, our model is flexible and facilitates a market-based solution adaptable for variable types and levels of diversity based upon the individual needs of companies without imposing significant costs. Therefore, for example, pursuant to a shareholder vote, cosmetics companies with products tailored to female consumers or high numbers of female employees might specify a higher target than mining companies without such attributes. We do not claim that shareholder empowerment and better monitoring of management are the sole or even primary reasons for promoting board diversity. Indeed, there are other powerful arguments for diversity, but these are not within the purview of corporate governance law. Therefore, rather than employing corporate disclosure as a blunt tool for the achievement of a sociopolitical goal, however worthy, our model is more modestly tailored to fit a specific governance goal: reducing agency costs by enabling better monitoring of management by shareholders. This preserves space for other kinds of legislation, if permissible under the constitution, to achieve gender equality.

The remainder of this Article is organized as follows: Part III provides an overview of the chief arguments advanced by the scholarly literature for board diversity. Part IV sketches legislative developments in a number

31. See Barrett, supra note 3. 
of countries including the United States, United Kingdom, Australia, and the European Union where a variety of legal approaches have been adopted to increase female representation on corporate boards. Part V outlines our proposal for a binding shareholder vote on diversity, and Part VI concludes.

\section{THE CASE FOR GENDER DIVERSITY}

There is a growing literature contributing to the debate on women's representation on corporate boards. ${ }^{32}$ Aside from theoretical work, an increasing volume of empirical scholarship seeks to identify the relationship between greater female representation and various aspects of firm performance, monitoring, and sustainability. ${ }^{33}$ The case for gender diversity can be constructed from this literature and grouped under the categories below.

\section{A. Diversity and Firm Performance}

The most often repeated raison d'etre for increasing board diversityat least as iterated by politicians and regulators - is that it makes a positive contribution to firm performance. ${ }^{34}$ To put it simply, diversity is good for the bottom line, and by their inattention to this issue businesses are not maximizing shareholder value. ${ }^{35}$ This vein of argument relies upon empirical studies reporting a positive correlation between firm performance and board diversity. ${ }^{36}$ A variety of methods for evaluating

32. See, e.g., LORD DAVIES OF ABERSOCH, supra note 4.

33. See, e.g., Why Women Are Good for Business, WoMEN On BoARDs (Dec. 2011), $\mathrm{http}$ ://www.womenonboards.org.au/pubs/articles/1112-why-women-are-good-for-business.htm.

34. See, e.g., LORD DAVIES OF ABERSOCH, supra note 4, at 7.

35. See id.

36. See Annu Kotiranta et Al., Finnish Bus. \& Policy Forum EVA, Female LEADERShIP AND FIRM PROFITABILITY (2007), http://www.europeanpwn.net/files/eva analysis_english.pdf; MiJINTJE LÜCKERATH-ROVERS, ERASMUS INST. OF MONITORING \& Compliance, The Dutch 'Female Board IndeX' 2010 (2010), http://www.tias.edu/ docs/default-source/Kennisartikelen/femaleboardindex2010.pdf?sfvrsn=12; Press Release, Thomson Reuters, Average Stock Price of Gender Diverse Corporate Boards Outperform Those with No Women (July 10, 2013), http://thomsonreuters.com/press-releases/ 072013/Average-Stock-Price-of-Gender-Diverse-Corporate-Boards-Outperform-Those-withNo-Women; Shivali Nayak, More Women in the Boardroom Can Improve Profitability: Pros, CNBC (Mar. 7, 2012, 10:24 PM), http://www.cnbc.com/id/46034361; Renuka Rayasam, Do More Women on the Board Mean Better Results?, NEW YORKER (Nov. 19, 
the potential effects of increased female boardroom presence are evident in the literature with some scholars employing the "natural experiment" provided by the implementation of Norwegian quota legislation.

The most high-profile reports, from Catalyst, assert that companies with more female board members have a 53\% higher return on equity, a $42 \%$ higher return on sales, and a $66 \%$ higher return on invested capital. ${ }^{37}$ These figures are based on a univariate analysis that ranked U.S. Fortune 500 companies by boardroom gender diversity and then compared the means of the highest and lowest quartiles with no attempt to control for other variables. ${ }^{38}$ There are obvious risks with such a method, especially the failure to control for other variables or consider causation. One of the earliest empirical studies - by David Carter, Betty Simkins, and W. Gary Simpson-showed that the positive relationship between diversity and Tobin's Q was significant even when controlled for firm size and other factors. ${ }^{39}$ Similarly, Ronald Anderson and others report that a $10 \%$ increase in board heterogeneity leads to a $7.49 \%$ increase in industry adjusted Tobin's Q with current board diversity predictive of future firm performance. ${ }^{40}$ This result includes consideration of both social diversity - age, ethnicity, and gender - and experiential diversity - education and employment background - but finds that each affects Tobin's Q to some extent. $^{41}$ These findings are applicable to firms with complex operations; Anderson hypothesizes that there are costs of managing diversity and these costs are outweighed by benefits in the case of complex operations but not in the case of firms with simple operations. ${ }^{42}$

Conversely, in a study of gender diversity on the boards of Swedish companies, Sven-Olov Daunfeldt and Niklas Rudholm argued that gender diversity has a negative effect on return on total assets after a time lag of two years. ${ }^{43}$ Using longitudinal data between 1997 and 2005, the study showed that there is no relationship between female board members and

2013), http://www.newyorker.com/business/currency/do-more-women-on-the-board-meanbetter-results; Why Women Are Good for Business, supra note 33.

37. Lois Joy et al., CATAlyst, The Bottom Line: Corporate Performance AND WOMEN'S REPRESENTATION ON BOARDS (2007), http://www.catalyst.org/system/files/

The_Bottom_Line_Corporate_Performance_and_Womens_Representation_on_Boards.pdf.

38. I $\bar{d}$.

39. David A. Carter et al., Corporate Governance, Board Diversity, and Firm Value, 38 FIN. REV. 33, 33, 36 (2003).

40. Ronald C. Anderson et al., The Economics of Director Heterogeneity, 40 FIN. MgmT. 5, 6 (2011).

41. Id. at 5-6.

42. Id. at 9 .

43. See Sven-Olov Daunfeldt \& Niklas Rudholm, Does Gender Diversity in the Boardroom Improve Firm Performance? 4 (Scandinavian Working Papers in Econ., HUI Working Paper No. 60, 2012), http://swopec.hhs.se/huiwps/abs/huiwps0060.htm. 
firm performance at the time of appointment but that there is a statistically significant difference-at $10 \%$ - from two years after appointment. ${ }^{44}$ However, their study does not evaluate potential reasons for the considerable heterogeneity on how more gender-balanced boards influence firm performance. ${ }^{45}$ Further, there is no information as to what occurs after the third year, and so assertions as to decreasing value cannot really be substantiated from the results. Another study that sought to analyze the impact of board diversity on firm performance showed a negative relationship. ${ }^{46}$ Renée Adams and Daniel Ferreira's study covered 85,000 U.S. directors and sought to identify the relationship between board diversity and governance by looking at board inputs such as attendance records and governance functions such as CEO oversight. ${ }^{47}$ They found that women have a better attendance record than men and that men attend meetings more regularly in gender diverse boards. ${ }^{48}$ However, only $2.38 \%$ of their observations involved board members meeting the SEC's $75 \%$ threshold of meetings not attended, ${ }^{49}$ and therefore the results might be capable of alternative explanations. Further, gender-diverse boards were more likely to see CEO turnover when the firm performed poorly. ${ }^{50}$ After a one standard deviation fall in stock price, the probability of CEO turnover was found to be $9.87 \%$, but in firms where the board was at least $40 \%$ female, this probability increased by $25.1 \% .{ }^{51}$ This may indicate that women are stronger monitors and more likely to hold CEOs accountable for performance. ${ }^{52}$ Adams and Ferreira also found that firms with greater board gender diversity have lower Tobin's Q and return on assets and suggested that this may be due to overmonitoring by the board. ${ }^{53}$ Adams and Ferreira therefore suggest that diversity might add value for companies that do not have strong monitoring of management. ${ }^{54}$ Other studies have suggested a positive relationship between board diversity and more

44. See id. at 8,20 .

45. See id. at 17-18.

46. Renée B. Adams \& Daniel Ferreira, Women in the Boardroom and Their Impact on Governance and Performance, 94 J. FIN. ECON. 291, 291 (2009).

47. See id. at $293-95$.

48. Id. at 292.

49. Id. at 296 .

50. See id. at 301.

51. Id.

52. See id.

53. Id. at 308 tbl.11.

54. Id. 
control over CEO pay by disrupting the selection of board members likely to support high pay. ${ }^{55}$

Several articles have reported on the effect of board diversity on firm performance using the natural experiment provided by Norway's quota legislation. Øyvind Bøhren and Øystein Strøm considered all of the nonfinancial firms on the Oslo Stock Exchange between 1989 and 2002 and found that firms with less gender diversity create more value. ${ }^{56}$ However, this study took place when females made up approximately $3 \%$ of directors, and even the authors note that the number of women in the sample they studied was so small that the results may not hold for a $40 \%$ quota situation. $^{57}$ From a study of 248 publically listed companies, Kenneth Ahern and Amy Dittmar suggest that the implementation of the Norwegian quota led to firms increasing in size, undertaking more acquisitions, increasing leverage, and reducing cash holdings. ${ }^{58}$ They argue that a compulsory $10 \%$ increase of female board members is associated with a $12.4 \%$ decline in Tobin's Q from the average. ${ }^{59}$ This analysis is based on a finding that those firms that already had at least one female board member when the quota was announced in 2002 had 2007 $\mathrm{Q}$ values that were 0.26 higher-in the context of an average $\mathrm{Q}$ of 1.53 than firms that had no female board members in 2002. ${ }^{60}$ This was based on the assumption that the greater increase in female participation represents a greater constraint on the firm's choices, and there was no control for the alternative possibility that firms with a longer history of gender diversity may experience long-term positive effects. ${ }^{61}$ Ahern and Dittmar observed that firms with no women on their board lost about 3.5\% of their value in the days immediately following the unanticipated 2002 announcement of quotas and used this as "evidence that the quota imposed significant and costly constraints on Norwegian firms." 62 Of course, market reaction cannot accurately measure the costs of a novel future change; the most a measurement of reaction can actually evidence is the

55. See James D. Westphal \& Edward J. Zajac, Who Shall Govern? CEO/Board Power, Demographic Similarity, and New Director Selection, 40 ADMIN. SCI. Q. 60, 79 (1995).

56. Øyvind Bøhren \& Øystein Strøm, Governance and Politics: Regulating Independence and Diversity in the Board Room, 37 J. Bus. FIN. \& ACCT. 1281, 1291, 1297 (2010).

57. See id. at 1298 .

58. Kenneth R. Ahern \& Amy K. Dittmar, The Changing of the Boards: The Impact of Firm Valuation of Mandated Female Board Representation, 127 Q.J. ECON. 137, 139, 141 (2012).

59. Id. at 140 .

60. Id. at $147-49,160$.

61. See id. at $160-68$.

62. Id. at $159-60$. 
opinion of a portion of the market regarding the predicted effect of the measures announced. Matsa and Miller further extrapolate that female directors increase overall costs because "they are more altruistic and longterm-oriented than male directors." ${ }^{63}$ In their research, Matsa and Miller persistently compare characteristics of new females with those of retained males, ${ }^{64}$ ignoring the more relevant issue of difference between new female directors and the men they replaced. Further, as noted within the Ahern \& Dittmar article, the study of a natural experiment such as Norway's implementation of quotas provides rich data but does not allow separate consideration of age, gender, and experience on firm value. ${ }^{65}$ Cathrine Seierstad and Tore Opsahl's consideration of the Norwegian quota implementation found an increase in women holding multiple board positions, ${ }^{66}$ suggesting that quota law merely offered more opportunities to a small number of women without having wider impact on women's opportunities. However, the focus on a small number of prolific "golden skirts"-women who hold positions on several boards - is rarely explained in the broader context. ${ }^{67}$ Although $15 \%$ of female directors in Norway hold two or three positions and $2 \%$ hold more than four positions, the same can be said of $10 \%$ and $1 \%$ of male directors, respectively, remembering that the absolute number of male directors remains higher than female directors. ${ }^{68}$ Considering the financial effects of female directors in the Norwegian context, Bøhren and Siv Staubo note that the negative financial effects observed were mostly limited to firms with low agency costs, which require less monitoring and more advice. ${ }^{69}$ They argue that the effects were the result of a dramatic increase in independent

63. Id. at 142 (quoting David A. Matsa \& Amalia R. Miller, A Female Style in Corporate Leadership? Evidence from Quotas, AM. ECON. J.: APPLIED ECON., July 2013, at 136,138$)$.

64. Id. (citing Masta \& Amalia, supra note 63.)

65. Id. at 188 .

66. Cathrine Seierstad \& Tore Opsahl, For the Few Not the Many? The Effects of Affirmative Action on Presence, Prominence, and Social Capital of Women Directors in Norway, 27 Scandinavian J. Mgmt. 44, 51-52 (2011).

67. See id.

68. Eva Tutchell \& John Edmonds, Made in Norway: How Norwegians Have Used Quotas to Increase the Number OF WOMEN ON COMPANy BoARds 28 (2013), http://fabianwomensnetwork.files.wordpress.com/2013/12/made_in_norway_web.pdf.

69. Øyvind Bøhren \& Siv Staubo, Mandatory Gender Balance and Board Independence, 21 Eur. FIn. MGMT. (forthcoming 2015) (manuscript at 21), http://papers.ssrn.com/sol3/ papers.cfm?abstract_id=2543871. 
directors, the unintended side effect of quota legislation. ${ }^{70}$ In other research studying those firms that avoided the quota legislation by changing company form, Bøhren and Staubo also found that firms with strong ownership and low agency costs were more likely to take action to avoid the costs of implementing the quota. ${ }^{71}$ Even in a natural experiment setting, it is very difficult to determine a specific generalizable link between female board members and firm profit.

In addition to the difficulty of separating specific board characteristics, there are various other theoretical difficulties in judging board behavior by firm financial outcomes such as endogeneity and the difficulty in obtaining reliable information from within the "black box" of board behavior. ${ }^{72}$ Adams, Benjamin Hermalin, and Michael Weisbach note the impossibility of overcoming endogeneity problems using the example of board size. ${ }^{73}$ Observing that the larger of two boards was associated with weaker financial performance, it would be tempting, they suggest, to conclude that larger boards weaken financial performance. ${ }^{74}$ However, without understanding the reasons why each board chose the size and structure, it is not possible to say whether board $A$ would improve its financial performance by emulating board $B .{ }^{75}$ Ultimately, pure statistics are unable to fully interrogate the unobserved variations between boards, firms, cultures, and contexts. In addition, the empirical literature is bedevilled by problems of reverse causation.

A study of actual board processes would be helpful instead of merely comparing input and outcome because it would overcome some of the theoretical limitations. Miriam Schwartz-Ziv's work provides an opportunity to appraise the actual processes by which male and female directors may affect board performance and, through this, firm performance. SchwartzZiv had access to detailed minutes of 402 board meetings from eleven Israeli government corporations. ${ }^{76}$ Coding the activities recorded, she found that boards with a critical mass - three or more - of each gender

70. Id. at 26-27.

71. See Øyvind Bøhren \& Siv Staubo, Does Mandatory Gender Balance Work? Changing Organizational Form To Avoid Board Upheaval, 28 J. CORP. FIN. 152, 154 (2014).

72. See Renée B. Adams et al., The Role of Boards of Directors in Corporate Governance: A Conceptual Framework and Survey, 48 J. ECON. LiTERATURE 58, 86 (2010).

73. See id. at 59-60.

74. See id. at 60.

75. See id. at 60-61.

76. Miriam Schwartz-Ziv, Does the Gender of Directors Matter? 12 (Harv. Univ. Edmond J. Safra Ctr. for Ethics, Working Paper No. 8, 2013), http://papers.ssrn.com/ sol3/papers.cfm?abstract_id=2257867. 
were more active. ${ }^{77}$ Where critical mass existed in a given meeting, the board was more likely to take initiative or request further information. ${ }^{78}$ Schwartz-Ziv argues that this behavioral finding gives weight to an argument that there is a causal link between gender diversity on boards and firm performance. ${ }^{79}$ It is the absence of a convincing causal explanation that weakens much of the literature seeking to measure the relationship between female board members and firm performance.

An emerging area of scholarship is investigating the relationship between board diversity and company performance in areas other than short-term shareholder wealth maximization. For instance, one study found there is no relationship between the number of women on the board and the company's responsiveness to climate change. ${ }^{80}$ A study of 200 Australian firms listed on the ASX found that increased representation of women was "positively linked with both economic growth and social responsiveness" but had "a non-significant relationship with environmental quality." 81

Despite the extensive focus on the assertion that additional female board members will create financial returns, the evidence is equivocal and the theoretical basis is shaky. ${ }^{82}$ The economic argument will invariably run into discussion of concerns about social justice. As Diane Brady comments, "[i]t's not good enough for a diverse board to be as good as

77. Id. at 7.

78. Id.

79. Id.

80. Jeremy Galbreath, Corporate Governance Practices That Address Climate Change: An Exploratory Study, 19 Bus. STRATEGY \& ENV'T 335, 346 (2010).

81. Jeremy Galbreath, Are There Gender-Related Influences on Corporate Sustainability? A Study of Women on Boards of Directors, 17 J. MGMT. \& ORG. 17, 29 (2011).

82. Some researchers argue there is a positive link between gender diversity and firm performance. See e.g., NANCY M. CARTER \& HARVEY M. WAGNER, CATALYST, THE BotTom Line: Corporate Performance and Women's Representation On BoArds (2004-2008), at 2 (2011), http://www.catalyst.org/system/files/the bottom line_corporate performance_and_women $\% 27$ s_representation_on_boards_\%282004-2008\%29.pdf; Anderson et al., supra note $\overline{4} 0$, at 6; David A. Carter et al., Corporate Governance, Board Diversity, and Firm Value, 38 Fin. REv. 33, 36 (2003). Some argue that there is a negative link. See, e.g., Ahern \& Dittmar, supra note 58, at 140; Bøhren \& Strøm, supra note 56, at 1284; Daunfeldt \& Rudholm, supra note 43, at 4; Yi Wang \& Bob Clift, Is There a "Business Case" for Board Diversity?, 21 PAC. ACcT. Rev. 88, 90 (2009); Lu Zhang, Board Demographic Diversity, Independence, and Corporate Social Performance, 12 CORP. Governance 686, 696 (2012). Others argue that there is a context-specific link. See, e.g., Adams \& Ferreira, supra note 46 , at 301. 
one that's only men. Those girls have to take your company to new levels of excellence to prove it's worth the headache of bringing them on." 83 And yet, as discussed above, women remain a small minority so "their individual contributions must be quite significant to be detected in studies of board performance." 84 One suggested discursive solution is, noting that there is no clear evidence that women affect firm performance, either for good or for evil, it must be left to the business community to provide proof as to why women would damage a firm if they seek to maintain genderhomogenous boards. ${ }^{85}$

Ultimately, even if the "business case" $" 86$ were capable of unequivocal proof, and even if such proof existed, the result would only serve to create one way in which firm value could be increased. Firms would have the responsibility of considering whether this mode of creating value was equal or superior to other modes, and women would thus be competing in a marketplace of value addition.

\section{B. Talent Pool}

Advocates for gender diversity have pointed to disproportionate representation on the board as evidence of poor utilization of the available talent pool composed of both sexes. This argument claims that the underutilization of a particular group - females-logically implies a decreased quality of board appointments. The talent pool argument was one of the six most common justifications for gender diversity on boards amongst directors interviewed by Lissa Broome and others ${ }^{87}$ and was also noted by scholars such as Zena Burgess and Phyllis Tharenou. ${ }^{88}$ However, given that the argument essentially requires evidence of a suboptimal level of quality in board appointments, it is generally not compelling at an individual firm level, especially because women are entitled to pursue board positions and firms have clear incentives to appoint the most qualified candidate regardless of sex. Further, there are likely to be less

83. Diane Brady, The Crumbling Case Against Women on U.S. Boards, Bus. WK. (Apr. 17, 2014), http://www.businessweek.com/printer/articles/195389-the-crumblingcase-against-women-on-u-dot-s-dot-boards.

84. Beate Elstad \& Gro Ladegard, Women on Corporate Boards: Key Influencers or Tokens?, 16 J. MgMt. Governance 595, 596 (2012).

85. See Barbara Black, Stalled: Gender Diversity on Corporate Boards, 37 U. DAYTON L. REV. 7, 20 (2011).

86. Id.

87. See Lissa L. Broome et al., Dangerous Categories: Narratives of Corporate Board Diversity, 89 N.C. L. REV. 759, 764 (2011).

88. Zena Burgess \& Phyllis Tharenou, Women Board Directors: Characteristics of the Few, 37 J. Bus. ETHICs 39, 40 (2002). 
intrusive options such as additional training and development of existing appointees.

The talent pool argument may have more power when mobilized at a national level. For example, a McKinsey Report notes "a failure to recruit and retain able women... exacerbate[s] the acute talent shortage," lamenting that the lack of women in senior positions is "a huge waste of talent ... . that Asian companies can ill afford." 89 The European Union's factsheet Women on Boards-The Economic Arguments also makes this argument, specifically referencing the fact that $60 \%$ of university graduates in Europe are women. ${ }^{90}$ Similarly, United Kingdom Prime Minister David Cameron argued the drive for more women in business "is not simply about equal opportunity, it's about effectiveness.... [I]f we fail to unlock the potential of women in the labour market,... we're failing our whole economy." 91 In the Australian context, the Grattan Institute suggests that a $6 \%$ increase in female workforce participation would lead to a $\$ 25$ billion increase in Australian gross domestic product, ${ }^{92}$ which is certainly an incentive to encourage full utilization of the talent pool at all levels. The talent pool argument is unlikely to provide motivation for individual firms to increase gender diversity on their boards but may provide a catalyst for legislative action at a national level.

\section{Attribute-Based Justifications}

Some arguments for increased female presence on corporate boards refer specifically to attributes that are perceived to be more common in women than in men. Drawing upon evidence of differences between men and women at a behavioral level, this strand of argument for diversity relies upon studies showing that women are more participative and democratic in their decisionmaking, more concerned with the welfare of

89. Claudia SÜSSMuth-Dyckerhoff et al., McKinsey \& Co., Women Matter: An Asian Perspective: Harnessing Female talent to Raise Corporate PERFORMANCE 1 (2012), http://www.mckinsey.com/global locations/asia/ /media/mckinsey $\% 20$ offices/japan/pdf/women_matter_an_asian_perspective.ashx.

90. EUROPEAN COMM’N , WOMEN $\overline{-}$ ON BOARDS-FACTSHEET 1: THE ECONOMIC ARGUMENTS 1 (2012), http://ec.europa.eu/justice/gender-equality/files/womenonboards/fact sheet-general-1_en.pdf.

91. David Cameron Won't Rule Out Women in Boardrooms Quotas, BBC News, http://www.bbc.com/news/uk-politics-16958852 (last updated Feb. 9, 2012, 6:47 AM).

92. John DALEy, GRATTAN InST., RePORT No. 2012-5, GAME CHANGERS: ECONOMIC REFORM PRIORITIES FOR AUSTRALIA 39 (2012). 
others, more sensitive, and more cooperative. For instance, Burgess and Tharenou note that women are considered to have a positive "influence on decision making and leadership styles," and play a role in "ensuring 'better' boardroom behavior." ${ }^{93}$ Under this umbrella, attributes like communicativeness, detailed focus, ${ }^{94}$ risk aversion, ${ }^{95}$ and intensive monitoring are likely to translate into ideal qualities for a board member in some contexts.

Some scholarship suggests that women are comparatively risk averse. For example Douglas Branson notes that "[w]omen are thought to be more sensitive and adverse to the sorts of risk that led to the global financial meltdown of 2008." 96 This "women could have saved the world" assertion features in numerous articles and is supported by research showing that women are less risk prone in certain situations. ${ }^{97}$ For example, an interesting trend noted in the Cesce Group Report is that companies with more than $40 \%$ women on their boards take on less credit than companies with a lower representation of women directors when compared with the whole business community. ${ }^{98}$ Similarly, a research study of hedge funds showed risk appetite on the trading floor resulted in women performing $56 \%$ better than men in the period of 2000 to 2009 , and in the height of the global financial crisis in 2008, men lost twice as much as women. ${ }^{99}$ Conversely, a Deutsche Bundesbank study in 2012 suggests an increase in the number of female board members will lead to an increase in firm risk-taking behavior. ${ }^{100}$ This study suffered from some issues regarding generalizability, for example, there were only twentyeight discrete instances of increased female board share out of nearly 20,000 bank-year observations. ${ }^{101}$ Furthermore, no consideration was given to the possibility that the existing directors might have changed their

93. Burgess \& Tharenou, supra note 88 , at 40 (citations omitted).

94. Martha C. White, Even One Woman on the Board Makes a Difference, NBC NEWs, (Jul. 21, 2014, 4:58 AM), http://www.nbcnews.com/business/business-news/evenone-woman-board-makes-difference-n158846.

95. Judy F. Graham et al., Gender Differences in Investment Strategies: An Information Processing Perspective, 20 InT'L J. BANK MARKETING 17, 17-18 (2002).

96. Douglas M. Branson, An Australian Perspective on a Global Phenomenon: Initiatives To Place Women on Corporate Boards of Directors, 27 AustL. J. CoRP. L. 2, 4 (2012).

97. See, e.g., Irene van Staveren, The Lehman Sisters Hypothesis, 38 CAMBrIDGE J. ECON. 995, 999 (2014).

98. María Pilar García Guijarro \& Ana Calvo Abril, Spain, in BREAKING THE GLASS Ceiling: Women in THE BoARdroom 98, 98-99 (Paul Hastings ed., 3d ed. 2013), http://www.paulhastings.com/genderparity/pdf/Gender_Parity_Report.pdf.

99. Van Staveren, supra note 97, at 999.

100. Allen N. Berger et Al., Deutsche Bundesbank No. 03/2012, Discussion

101. See id. at 6,16 . 
own risk appetite in the presence of females - or younger directors or Ph.D. holders. ${ }^{102}$ There is empirical literature suggesting that men often alter their behavior in the presence of women. ${ }^{103}$ Van Staveren refers to a study of online chess players that considered 1,400,000 games of 15,000 players and found that male players choose more aggressive strategies when playing against female players. ${ }^{104}$ This is the case even when such a strategy reduces the man's chances of winning. ${ }^{105}$ In fact, the increase in aggression is most pronounced when the man is objectively-according to chess ranking - less skilled than the female player. ${ }^{106}$ In addition to the lack of clarity over whether females take greater or lesser risks, there is no certainty over whether risk is a positive or negative trait. ${ }^{107}$ This would likely depend on the industry and context.

Many of the arguments for increasing the number of women on boards relate to the perception that women are better at problem solving and more able to engage in constructive dissent. ${ }^{108}$ Robert McCord of the proxy advisory firm Glass Lewis LLC claimed that "[w]omen are more likely to ask tough questions, get detailed answers and push for collaborative solutions."109 Indeed, Schwartz-Ziv was able to go within the black box and discover that there are specific differences between male and female boardroom behaviors. Schwartz-Ziv found that boards with critical mass of female directors are more likely to take action - by making a decision or asking for further information-and more likely to experience CEO turnover as a response to weak performance. ${ }^{110}$ Schwartz-Ziv also showed some causality to the relationship between female directors and firm performance. ${ }^{111}$ The issue of tough questions relates to the monitoring function of the board, which has been found to be positive or negative depending on the governance style of the particular firm. Adams and Ferreira found that overmonitoring was responsible for a reduction in

102. See id. at 39.

103. Van Staveren, supra note 97, at 998-99, 1010.

104. Id. at 1000 n.2, 1001 .

105. Id. at 1000 n.2.

106. Id. at 1001 .

107. See id.

108. Broome et al., supra note 87 , at 764 .

109. Branson, supra note 96, at 18 (citing Kris B. Mamula, Pa. Treasurer Robert McCord Advances Issue of Women on Corporate Boards, PitT. Bus. Times, Apr. 8, 2011, 2011 WLNR 6860521).

110. Schwartz-Ziv, supra note 76, at 7, 22.

111. See id. at 22 . 
firm value after increase in female board participation. ${ }^{112}$ Similarly, Bøhren and Staubo found that firm value responses to Norway's quota legislation were likely to be the result of an increase in independent directors. ${ }^{113}$ Just as in the example of risk appetite, even if there was a specific link between female directors and monitoring style, ideal monitoring style varies greatly between firms.

Even where certain feminine traits are considered to be advantageous to board performance, simply adding women to a corporation's board is not necessarily the solution. Yvonne Billing and Mats Alvesson argue that, rather than implementing a simple "add women" formula, characteristics perceived as "feminine" should be considered as a way to expand our understanding of management and leadership. ${ }^{114}$ Further complicating the use of feminine characteristics as an argument to appoint more female directors, studies have shown that the female advantage in these areas can be artificially replicated. For example, one measurable difference between male and female stress response is the female tendency to increase beneficial production of oxytocin, which enhances cooperation. ${ }^{115}$ However, men receiving a nasal spray of oxytocin also increased their cooperative approach. ${ }^{16}$ If the core motivation for pursuing gender diversity on boards were to be the specific female traits that could be accessed, this might be achieved by oxytocin delivered to male board members. Although such a suggestion appears flippant, it does highlight a weakness in reliance on business case arguments: there is always an alternative business case. Moreover, the gender attribute line of argument stereotypes women and conflates group attributes with individual level capabilities. Women who reach board positions may not necessarily possess these attributes and may indeed lack them because of habituation in male-specific traits. Equally, men might share some of these qualities or acquire them by socialization. Further, even if all women could be uniformly asserted to have these traits, the traits may not be actively utilized in board activity. ${ }^{117}$

112. Adams \& Ferreira, supra note 46, at 304-05.

113. Bøhren \& Staubo, supra note 71, at 165.

114. See Yvonne Due Billing \& Mats Alvesson, Questioning the Notion of Feminine Leadership: A Critical Perspective on the Gender Labelling of Leadership, 7 GENDER, WORK AND ORG. 144, 144 (2000).

115. Van Staveren, supra note 97 , at 1003-04.

116. Id. at 1004 .

117. See Billing \& Alvesson, supra note 114, at 148. 


\section{Trust and Signaling}

In theory, the board exists to minimize the information asymmetries between shareholders and management and to exercise oversight over the latter in order to ensure they do not divert corporate resources to their own ends. Therefore, the board is saddled with legal duties to act in good faith and to work for the success of the company as a whole. Specific legal provisions impose obligations on directors to be long-term oriented in their thinking, pay due regard to the interests of the firm's employees and its business reputation, and consider stakeholders - business partners, consumers, local communities where they operate - and the physical environment. These are supplemented by a general duty to act fairly in balancing conflicts between the various stakeholder interests as are likely to occur frequently with a recognition that shareholder interests are primary. ${ }^{118}$

The effective discharge of these obligations requires trust from both shareholders and other key constituencies including employees and consumers. The levels of gender disparity currently observed on corporate boards in countries such as the United States, the United Kingdom, and Australia are unlikely to be conducive to the generation of such trust in a milieu where over $50 \%$ of the labor market and higher educated population is comprised of women. ${ }^{119}$ Therefore, unsurprisingly, a frequently advanced argument for increasing the number of women on boards is the signal to employees, shareholders, stakeholders, and the market as a whole that the board is worthy of trust. ${ }^{120}$

Directors interviewed by Broome list signaling among the top reasons for board diversity, ${ }^{121}$ as do Burgess and Tharenou. ${ }^{122}$ There are also suggestions that "a diverse board helps the organization to attract and

118. See James M. Tobin, The Squeeze on Directors-Inside Is Out, 49 Bus. LAw. 1707, 1709 (1994).

119. ORG. FOR ECON. CO-OPERATION \& Dev., Enhancing WOMEn's ECONOMiC EMPOWERMENT THROUGH ENTREPRENEURSHIP AND BusineSS LEADERSHIP IN OECD COUNTRIES 40-41 (2014), http://www.oecd.org/gender/Enhancing\%20Women\%20Economic $\% 20$ Empowerment_Fin_1_Oct_2014.pdf.

120. Board Brief: Why Gender Diversity Matters, Tex. Wall St. Women, http://www.txwsw.com/pdf/board_brief.pdf (last visited Mar. 30, 2015).

121. Broome et al., supra note 87, at 762-64; see Lissa Lamkin Broome \& Kimberly D. Krawiec, Signaling Through Board Diversity: Is Anyone Listening?, 77 U. CIN. L. REV. 431, 431 (2008) (noting that the "signaling theory" figured most prominently in interviews regarding rationales for board diversity).

122. See Burgess \& Tharenou, supra note 88 , at 40. 
retain diverse talents." 123 Research shows that diversity is a signal to the community that the company places a high value on women. ${ }^{124}$

A signal is a clearly identifiable behavior that serves to denote the existence of a less observable, more amorphous behavior or characteristic. ${ }^{125}$ Signals are most effective when they are cheap to send for those possessing the characteristic and expensive for those not possessing the characteristic. ${ }^{126}$ Patrick Shin and Mitu Gulati use the example of working long hours, which operates as a signal attempting to denote the underlying characteristic of being a hardworking individual. ${ }^{127}$ Signaling behavior can serve to indicate either differentiation or group identity. ${ }^{128}$ In the present instance, board diversity may operate as a separation signal —our company is different because we care about social justice issues - or an identification signal - our company is part of the group that cares about social justice issues. Shin and Gulati claim that diversity is a vague notion and better understood as showcasing, given the context in which there are extremely limited instances of true diversity and an intention to show diversity may be valued and considered sufficient. ${ }^{129}$ The difficulty is that even the showcasing signal might be dismissed if it is too cheap to send and false signalers cannot be punished. Notably, at least one director interviewed by Broome dismissed the prospect of board diversity as "a meaningless public relations maneuver" indicating the cheap value of the signal. ${ }^{130}$

\section{E. Summary}

The case for diversity transcends a direct contribution to firm profits. Even when empirical studies show an association between corporate gender diversity and improved firm performance, the causal relationship is not entirely clear. Some of the most persuasive evidence about the ability of diverse boards to improve firm performance concerns the role of the board in monitoring management. This evidence suggests that

123. Muhammad Ali et al., Board Age and Gender Diversity: A Test of Competing Linear and Curvilinear Predictions, 125 J. Bus. ETHICs 497, 499 (2014) (citation omitted).

124. See Stephen Bear et al., The Impact of Board Diversity and Gender Composition on Corporate Social Responsibility and Firm Reputation, 97 J. Bus. ETHICs 207, 207 (2010); Amy J. Hillman et al., Organizational Predictors of Women on Corporate Boards, 50 ACAD. MGMT. J. 941, 944 (2007).

125. See Patrick S. Shin \& Mitu Gulati, Showcasing Diversity, 89 N.C. L. REV. 1017, 1022-23 (2011).

126. Id. at 1023 .

127. Id.

128. Id. at $1022-23$.

129. See id. at 1038 .

130. Broome et al., supra note 87 , at 764 . 
boards with a critical mass of female directors perform better at monitoring and holding CEOs accountable; this insight is central to the key aims of corporate governance law. Therefore, our proposal is closely tied to optimizing the monitoring function and thereby reducing agency costs.

\section{COMPARATIVE LEGAL APPROACHES}

This section offers an overview of diversity initiatives in five countries and the European Union. These exhibit a variety of normative goals and are not always characterized by consistency between goals and solution design. While the Norwegian legislation appears to be motivated by talent pool considerations, the European Union's proposed directive is animated both by social justice and economic arguments. The United Kingdom approach is supportive of diversity with the actual steps being left to businesses.

Regardless of normative consistency and clarity, quotas are a growing trend. A number of countries have implemented some form of gender quota for corporate boards in recent years, including Belgium, ${ }^{131}$ France, ${ }^{132}$

131. See Loi modifiant la loi du 21 mars 1991 portant réforme de certaines enterprises publiques économiques, le Code des sociétés et la loi du 19 avril 2002 relative à la rationalisation du fonctionnement et de la gestion de la Loterie Nationale afin de garantir la présence des femmes dans le conseil d'administration des enterprises publiques autonomes, des sociétés cotées et de la Loterie Nationale [Law Modifying the Law of March 21, 1991 Reforming Certain Public Economic Enterprises, the Belgian Company Code and the Act of April 19, 2002 on the Rationalization of the Function and Management of a National Lottery to Ensure the Presence of Women on the Board of Autonomous Public Enterprises, Listed Companies, and the National Lottery] of June 16, 2011, Moniteur Belge [M.B.] [Official Gazette of Belgium], Sept. 14, 2011, 2d. ed., http://www.lachambre.be/FLWB/pdf/53/0211/53K0211012.pdf.

132. See Loi 2011-103 du 27 janvier 2011 relative à la représentation équilibrée des femmes et des hommes au sein des conseils d'administration et de surveillance et à l'égalité professionnelle [Law 2011-103 of January 27, 2011 on the Balanced Representation of Men and Women on Boards of Directors and Supervisory and Professional Equality], JOURNAL OfFICIEL DE LA RÉPUBLIQUE FRANÇAISE [J.O.] [Official Gazette of France], Jan. 28, 2011, p. 1680, http://www.assemblee-nationale.fr/13/pdf/ta/ ta0592.pdf. 
Iceland, ${ }^{133}$ India, ${ }^{134}$ Italy, ${ }^{135}$ Malaysia, ${ }^{136}$ Netherlands, ${ }^{137}$ Slovenia, ${ }^{138}$ Spain, ${ }^{139}$ and the United Arab Emirates. ${ }^{140}$ An even greater number of countries have implemented quotas that are only applicable to stateowned enterprises, some of which predate the Norwegian legislation. ${ }^{141}$ In addition, various countries are currently considering proposals to implement quotas for nongovernment companies, such as Brazil, Canada, Germany, Philippines, South Africa, and Switzerland. ${ }^{142}$ Other countries have employed recommendations in their corporate governance codes rather than legislation to advance diversity, including Albania, ${ }^{143}$ Austria, ${ }^{144}$

133. See European COMM'N, EXCHANGE OF GoOd Practices on GENDER EQUALITY 3 (2012), ec.europa.eu/justice/gender-equality/files/exchange_of_good_practice_no/is_ comments_paper_no_2012_en.pdf.

134. See The Companies Act, 2013, No. 18, Acts of Parliament, 2013 (India), http://indiacode.nic.in/acts-in-pdf/182013.pdf.

135. See Legge 12 luglio 2011, n.120, in G.U. July 28, 2011, n. 174 (It.), http://www. giustizia.lazio.it/appello.it/pari_opp/120.pdf.

136. See Mazwin Nik Anis, PM: 30\% of Corporate Decision-Makers Must Be Women, STAR, http://www.thestar.com.my/story/?file= $\% 2 \mathrm{f} 2011 \% 2 \mathrm{f} 6 \% 2 \mathrm{f} 27 \% 2$ fnation $\% 2$ f20110627131533\&sec=nation (last updated June 27, 2011, 3:43 PM).

137. See Wet van 6 juni 2011 tot wijziging van boek 2 van het Burgerlijk Wetboek in verband met de aanpassing van regels over bestuur en toezicht in naamloze en besloten vennootschappen [Act of June 6, 2011 To Amend Book 2 of the Civil Code in Connection with the Adjustment to Rules on Management and Control in Public and Private Companies], Stb. 2011 (Neth.), www.eerstekamer.nl/9370000/1/j9vvhwtbnzpbzzc/viqscpzp $6 \mathrm{bnu} / \mathrm{f}=\mathrm{y} \cdot \mathrm{pdf}$

138. See European Comm'n, Women in DeCision-MaKing, supra note 11, at 19.

139. See Constitutional Act 3/2007 of 22 March for Effective Equality Between Women and Men (B.O.E. 2007, 71) (Spain).

140. See Sara Hamdan, U.A.E. Promotes Women in the Boardroom, N.Y. TIMES (Dec. 19, 2012), http://www.nytimes.com/2012/12/20/world/middleeast/uae-requireswomen-board-members.html?_r=0\&pagewanted=print.

141. See, e.g., Konstañtina Davaki, European Parliament, The Policy on GENDER EQuAlity In GREeCE 9 (2013); Tomer Maharshak \& Roy Wiesner, Israel, in BREAKING THE GLASS CEILING: WOMEN IN THE BOARDROOM, supra note 98, at 118-19.

142. See Michelle Yetter, Canada, in Breaking The Glass CeILING: Women IN THE BOARDROOM, supra note 98, at 20-21. The newly elected German coalition government has agreed to implement a $30 \%$ quota on supervisory boards with draft legislation currently with various ministries for comment. See, e.g., Saskia MacLaughlin, Update on Women's Quota on Supervisory Boards, DLA PIPER (June 24, 2014), http://blogs.dlapiper.com/ employmentgermany/2014/06/24/update-on-womens-quota-on-supervisory-boards/.

143. See Elda Dollija \& Manjola Çollaku, Women and Glass Ceiling in Albania, 4 MEditerRaneAn J. SOC. SCI. 720, 722 (2013).

144. See Austrian Working GrP. For Corporate Governance, Austrian Code OF CORPORATE GOVERNANCE 33-34 (2012), http://www.wienerborse.at/corporate/pdf/ CG\%20Codex\%202012_v5_englisch.pdf. 
Bangladesh, ${ }^{145}$ Jordan, ${ }^{146}$ Luxembourg, ${ }^{147}$ Malawi, ${ }^{148}$ Pakistan, ${ }^{149}$ Singapore, ${ }^{150}$ and Trinidad and Tobago. ${ }^{151}$ Australia, ${ }^{152}$ Denmark, ${ }^{153}$ and Sweden ${ }^{154}$ each have a "comply or explain" model, which requires targets for gender equity and reporting. An overview of the key pieces of legislation follows.

\section{A. Norway}

Norway is the pioneer of board gender quotas. ${ }^{155}$ There, corporate gender diversity legislation must be understood with reference to the broader social contexts of a strong, state-based family welfare provision and gender equality. ${ }^{156}$ The country has employed quotas to improve

145. See Taskforce on Corporate Governance, The Code Of Corporate GOVERNANCE FOR BANGLADESH 49 (2004), http://www.ecgi.org/codes/documents/code.pdf.

146. See COMPANIES Control DeP'T, Jordanian Corporate Governance Code 4 (n.d.), https://www.sdc.com.jo/english/images/stories/pdf/corporateguidee.pdf.

147. See Bourse de LuXembourg, Corporate Governance: The X PrinciPles of Corporate Governance of the LuXeMBOURG StOCK ExCHANGE 14 (3 ed. rev. 2013), http://www.kpmg.com/lu/en/topics/auditcommittee/documents/10principlesofcorporateg overnanceofluxembourgstockexchange-2013.pdf.

148. See Malawi Inst. of Dirs., Code of Best Practice for Corporate GOVERNANCE IN MALAWI 17 (2010), http://www.ecgi.org/codes/documents/malawi_codeii _1jun2010_en.pdf.

149. See Sec. \& EXch. Comm'n of PAK., Code of Corporate Governance 5 (2012), http://www.secp.gov.pk/CG/CodeOfCorporateGovernance_2012.pdf.

150. See Monetary AUTH. OF Sing., Code of Corporate Governance 6 (2012), http://www.mas.gov.sg/ /media/resource/fin_development/corporate_governance/CGCR evisedCodeofCorporateGovernance3May2012.pdf.

151. See CaribBean Corporate Governance Inst. et AL., Trinidad And Tobago CORPORATE GOVERNANCE CODE 2013, at 13 (2013), http://www.ecgi.org/codes/documents/ trinidad_tobago_cgcode_26nov2013_en.pdf.

152. See ASX Corporate Governance Council, Corporate Governance PRINCIPLES AND RECOMMENDATIONS 11 (3d ed. 2014), http://www.asx.com.au/documents/ asx-compliance/cgc-principles-and-recommendations-3rd-edn.pdf.

153. See DENMARK COMMITTEE ON CORPORATE GOVERNANCE, RECOMMENDATIONS ON CORPORATE GOVERNANCE 11 (2010), http://corporategovernance.dk/file/291826/

154. See Deloitte, Women in the Boardroom: A Global Perspective 27 (3d ed. 2013), http://deloitte.wsj.com/riskandcompliance/files/2013/05/women_boardroom.pdf.

155. Aagoth Storvik \& Mari Teigen, Women on Board: The Norwegian EXPERIENCE 3 (2010), http://library.fes.de/pdf-files/id/ipa/07309.pdf.

156. Siri A. Terjesen et al., Legislating a Woman's Seat on the Board: Institutional Factors Driving Gender Quotas for Boards of Directors, J. Bus. ETHICS 5 (Feb. 25, 2014), http://0-download.springer.com.sally.sandiego.edu/static/pdf/364/art\%253A10.1007\%252 Fs10551-014-2083-1.pdf?auth66=1421877887_30e36c18969ec80c793321e7195271aa\& 
gender equity in other fields, for example the Gender Equality Act of 1981 required at least $40 \%$ of each gender on publicly appointed boards, councils, and committees. ${ }^{157}$ Despite this history, the introduction of board quotas in 2002 came as a surprise - even the then minister of Trade and Industry described the announcement as "terrorist tactics."

The genesis for the quota came from proposals put forward in October 1999 by Valgerd Svarstad Haugland, Minister for Gender Equality under the Kjell Bondevik government, to amend the Gender Equality Act of 1978 to extend quotas applicable to government companies to privately owned companies. ${ }^{159}$ Over time, these changes were transferred to the Companies Act, and legislation was passed in 2003 after Bondevik returned to power following a period in opposition. ${ }^{160}$ Despite political support for the proposal, the Confederation of Norwegian Business and Industry (Næringslivets Hovedorganisasjon, NHO) considered the proposal "unnecessary, because voluntary efforts are already being made to increase the recruitment of women to company boards." 161 In its final form, the legal scheme allowed the business community an opportunity to enhance gender diversity with mandatory quotas taking effect if voluntary efforts did not bear fruit.

The Norwegian legislation was likely motivated by a social justice mission in addition to the talent pool argument. For instance, the then State Secretary in Norway's Ministry for Children and Equality, Kjell Erik Øie, in a speech to the Economic Commission for Europe in 2007 explained that

[w]e also see this as an important factor in the creation of wealth in society. [It] will secure women's influence in decision making processes of great importance for the economy.... Women of today are highly educated and we need their competence in all spheres and sector in the labour market. 162

ext=.pdf; see generally Darren Rosenblum, Feminizing Capital: A Corporate Imperative, 6 BERKELEY BUS. L.J. 55, 67-68 (2010) (asserting that in Norway, striving for gender equality in the public and private sectors involves an adequate welfare system and good governance in boardrooms).

157. Alice Lee, Gender Quotas Worked in Norway. Why Not Here?, New RePuBLIC (Sept. 5, 2014), http://www.newrepublic.com/article/119343/impact-quotas-corporategender-equality.

158. Ahern \& Dittmar, supra note 58, at 155.

159. STORVIK \& TEIGEN, supra note 155 , at 7.

160. See id. at 6 .

161. Kristine Nergaard, Government Proposes Gender Quotas on Company Boards, EUROFOUND, http://www.eurofound.europa.eu/eiro/2003/06/feature/no0306106f.htm (last updated June 25, 2003).

162. Kjell Erik Øie, State Sec'y, Ministry for Children and Equal., Nor., Keynote Speech at The Economics of Gender Session of the Economic Commission for Europe, 60th Anniversary Session: Gender Equality: A Key Component of a Modern Growth 
Similarly, the then Minister for Children, Equality, and Social Inclusion, Audun Lysbakken, claimed that "gender equality [is] a prerequisite and key factor for economic growth. ... If we neglect the need to empower women; [w] pay for that neglect by weakening our countr[y's] economic performance." 163 This focus is also reflected in comments made by drafters of the relevant legislation. ${ }^{164}$ The fact sheet published by the Norwegian Ministry of Trade, Industry, and Fisheries on the legislation begins with the paragraph, "In Norway, a high number of women are employed. Three out of five students in universities and colleges are women. However, over the past years, the number of women on company boards has remained relatively small." 165

Norway's quota provisions were inserted into Chapter 6 of the Companies Act, which covers company management. ${ }^{166}$ This chapter already included sections requiring that at least half of all directors on any board were residents of Norway ${ }^{167}$ and sections dealing with employee representatives. ${ }^{168}$ In this context, the gender parity requirement is on similar lines. Section $6-11 \mathrm{a}$ is the operative provision for a public limited liability board:

(1) On the board of directors of public limited liability companies, both sexes shall be represented in the following manner:

1. If the board of directors has two or three members, both sexes shall be represented.

Strategy (Apr. 27, 2007), http://www.norway-geneva.org/ARKIV/gender270407/\#.VE $75 \mathrm{X} 4 \mathrm{vF} 8 \mathrm{U} 4$.

163. Audun Lysbakken, Ministry of Children, Equal., and Soc. Inclusion, Speech to the Global Roundtable on Board Diversity: An overview of the Gender Quotation on Company Boards in Norway (Mar. 30, 2010), http://www.regjeringen.no/en/archive/ Stoltenbergs-2nd-Government/bld-2/taler-og-artikler/2010/global-roundtable-on-boarddiversity.html?id=599588.

164. See Rosenblum, supra note 156, at 66 n.59 (reporting on an interview with Aud Slettemoen, counsel at the Ministry of Justice and drafter of Norway's corporate board quota).

165. Fact Sheet: The Legislation on Representation of Both Sexes in Boards, NORWAY MINISTRY OF TRADE, INDUS., AND FISHERIES, http://www.regjeringen.no/en/dep/ $\mathrm{nfd} /$ press-centre/fact-sheets/fact-sheet-the-legislation-on-representa.html?regj_oss=1\&id=641 431 (last updated Sept. 19, 2011).

166. See Norwegian Public Limited Liability Companies Act, June 13, 1997, § 6$11 \mathrm{a}$.

167. Id. $\S 6-11$.

168. Id. $\S \S 6-4,6-5$. 
2. If the board of directors has four or five members, each sex shall be represented by at least two members.

3. If the board of directors has six to eight members, each sex shall be represented by at least three members.

4. If the board of directors has nine members, each sex shall be represented by at least four members, and if the board of directors has more members, each sex shall be represented by at least 40 percent of the members of the board. ${ }^{169}$

The quota shall not apply where there is less than $20 \%$ of either gender in the company's workforce. ${ }^{170}$ These amendments to the Companies Act were added on December 19, 2003, but companies were given until the end of 2005 to make voluntary arrangements. ${ }^{171}$ When these efforts were not satisfactory, the law entered into force on January 1, 2006, with a requirement that the mandatory quotas be achieved by $2008 .{ }^{172}$ Compliance appears to have been high in the ensuing years with only seventy-seven companies out of about 450 being in breach on January 2008. ${ }^{173}$ These companies received warning letters from the Brønnøysund Registration Centre, which gave them four weeks to comply. ${ }^{174}$ In February 2008, only twelve companies required a second letter, and by April 2008, all were compliant. ${ }^{175}$ It is noteworthy that the quota provisions were backed by a dissolution sanction in the Companies Act, and this threat appears to have aided compliance. ${ }^{176}$ Remarkably, in the ensuing years the Norwegian business landscape appears to have overcome initial opposition to the quotas, ${ }^{177}$ and there is now widespread support. ${ }^{178}$

169. Id. § 6-11a.

170. Id. ("The first paragraph does not apply to ... directors who have been elected among the employees pursuant to $\S 6-4$ or $\S 6-37$ first paragraph. When two or more ... directors as mentioned in the first paragraph are elected, both sexes shall be represented. The same applies to deputy directors. ... [T] he second and third sentence[s] do not apply if one of the sexes is represented by less than 20 percent of the total number of employees in the company at the time of election.").

171. STORVIK \& TeIGEN, supra note 155 , at 5.

172. Id.

173. Id. at 9 .

174. Id.

175. Id

176. Id. at $8-9$.

177. See, e.g., Jabeen Bhatti, The Quota Wars, ATlantiC TIMES, http://www.theatlantic-times.com/index.php?option $=$ com_content\&view $=$ article $\& i d=462 \% 3$ Athe-quota-wars \&catid $=25 \% 3$ Apolitics\&Itemid=2 (last visited Mar. 30, 2015).

178. See TUTCHELL \& EDMONDS, supra note 68, at 39. 


\section{B. The European Union}

Fewer than $18 \%$ of the board positions on 610 of the largest public companies in twenty-eight member states in the European Union are held by women. ${ }^{179}$ Although the numbers are a poor reflection of gender equality, it is noteworthy that they have risen from $8.5 \%$ in early 2003 to $17.8 \%$ in October 2013 - more than double in just a decade. ${ }^{180}$ A mere $3 \%$ of these companies have women as CEOs. ${ }^{181}$ The largest percentage growth has been witnessed in countries where legislation has been introduced or considered in a milieu of public attention to the topic. ${ }^{182}$

Against this record of low representation and political unease, the European Union proposed a directive for a procedural quota for board appointments on November 14, 2012. ${ }^{183}$ The proposed directive would require any company that does not have a minimum of $40 \%$ of each sex on its board of directors by 2020 to provide details of their appointment process. ${ }^{184}$ A year later, on November 20, 2013, the European Parliament voted to adopt the law, and it is now before the Council of the European Union. ${ }^{185}$

The impetus for the proposed directive appears to have been provided by a call from European Commission Vice President Viviane Reding for listed corporations to sign the "Women on Board Pledge"-voluntarily committing to increase women's presence on their boards to $30 \%$ by 2015 and $40 \%$ by $2020 .{ }^{186}$ Companies were to make this commitment by

179. European Comm'n, Gender Balance on Corporate Boards: Europe Is CRACKING THE GLASS CEILING 1 (2014), http://ec.europa.eu/justice/gender-equality/files/ documents/140303_factsheet_wob_en.pdf.

180. Id. at 2.

181. See id.

182. See id. at 3.

183. See Press Release, European Comm'n, Women on Boards: Commission Proposes 40\% Objective (Nov. 14, 2012) [hereinafter Press Release, 40\% Objective], http://europa.eu/rapid/press-release_IP-12-1205_en.pdf.

184. See id. Specifically, the directive requires $40 \%$ of nonexecutive directors to be members of the underrepresented sex. Id.

185. See European Parliament Legislative Resolution of 20 November 2013 on the Proposal for a Directive of the European Parliament and of the Council on Improving the Gender Balance Among Non-Executive Directors of Companies Listed on Stock Exchanges and Related Measures, COM (2012) 614 final (Nov. 20, 2013) [hereinafter European Parliament Legislative Resolution], http://www.europarl.europa.eu/sides/get Doc.do?type=TA\&reference=P7-TA-2013-0488\&language=EN\&ring=A7-2013-0340.

186. See Press Release, Women on the Board Pledge, supra note 11. 
International Women's Day on March 8, 2012,187 with the threat that "if self-regulation fails, I am prepared to take further action at EU level." Predictably, a mere twenty-four corporations signed the pledge in 2012, and the representation of women on European boards had only increased marginally from $11.8 \%$ to $13.7 \%{ }^{189}$ Reding was not satisfied with the results ${ }^{190}$ and proposed a directive establishing a quota for member states. ${ }^{191}$

The European Commission then initiated consultation, claiming that " $t \mathrm{t}]$ he lack of women in top jobs in the business world harms Europe's competitiveness and hampers economic growth." ${ }^{.192}$ Six national parliaments, including the United Kingdom, made submissions to the European Commission noting that the proposed measures did not comply with the principle of subsidiarity and that member states should be free and responsible to initiate programs of reform. ${ }^{193}$ In total, 485 replies were received-161 were from individual and 324 were from organizations, including 13 member states, 3 regional governments, 6 cities or municipalities, 79 companies, 56 business associations, and 53 nongovernment organizations - when the consultation period ended on May 28, 2012. ${ }^{194}$ The arguments for women on boards varies, but there was strong and frequent mention of the economic potential of the women who are qualified to take on more senior board roles: " $\mathrm{t}[\mathrm{t}] \mathrm{his}$ underused pool of qualified workers represents an untapped potential for the economy." 195

187. Id.

188. Press Release, European Comm'n, EU Justice Commissioner Viviane Reding Meets European Business Leaders To Push for More Women in Boardrooms (Mar. 1, 2011) [hereinafter Press Release, Reding Push for More Women], http://europa.eu/rapid/ press-release_IP-11-242_en.htm

189. EUROPEAN COMM'N, WOMEN IN DeCiSION-MAKING, supra note 11, at 15.

190. Press Release, European Comm'n, European Commission Weighs Options To Break the 'Glass Ceiling' For Women on Company Boards (Mar. 5, 2012), [hereinafter Press Release, European Commission Weighs Options], http://europa.eu/rapid/pressrelease_IP-12-213_en.pdf.

191. $\quad$ Press Rèlease, 40\% Objective, supra note 183.

192. Press Release, European Commission Weighs Options, supra note 190.

193. See Consultation on Gender Imbalance in Corporate Boards in the EU, EUR. COMMISSION (May 28, 2012), http://ec.europa.eu/justice/newsroom/gender-equality/opinion/ 120528 en.htm; Gov't Equals. Office, Dep't for Bus. Innovation, \& Skills, UK Response to the European Commission Consultation on Gender Imbalance in Corporate Boards in the EU, EUR. UNION (May 2012), http://ec.europa.eu/justice/newsroom/gender-equality/ opinion/files/120528/pa/298_en.pdf.

194. Proposal for a Directive of the European Parliament and of the Council on Improving the Gender Balance Among Non-Executive Directors of Companies Listed on Stock Exchanges and Related Measures, at 7, COM (2012) 614 final (Nov. 14, 2012) [hereinafter Proposal for a Directive], http://eur-lex.europa.eu/legal-content/EN/TXT/ PDF/?uri=CELEX:52012PC0614\& from=EN.

195. Press Release, Reding Push for More Women, supra note 188. 
Article 157(3) of the Treaty on the Functioning of the European Union (TFEU) is the source of power for the proposed directive. ${ }^{196}$ Previous Court of Justice of the European Union (CJEU) decisions interpreting this article held that where there is an opaque pay structure and a statistical inequality between the sexes can be demonstrated, the burden of proof shifts to the employer to prove that there is a nondiscriminatory reason for the statistical inequality. ${ }^{197}$ Although not explicitly stated within the proposed directive, this argument seems to be doing much of the work. The process of appointment is opaque and not open to scrutiny, yet the data demonstrates a clear practical discrepancy between the number of men and women on boards. Notably, case law places limits on the positive discrimination that can be applied; it can only be effective to give priority to equally qualified female candidates over male candidates. ${ }^{198}$ Therefore, the Norwegian model would not be permissible because it would require the appointment of a less qualified female despite the availability of a more qualified male. ${ }^{199}$

The directive in the form adopted by the European Union Parliament is designed to "ensure a more balanced representation of men and women" in appointments to nonexecutive director positions of listed companies "by establishing effective measures aimed at accelerated progress towards gender balance while allowing companies sufficient time to make the necessary arrangements. $" 200$ It applies to listed companies, which are defined as companies with a seat "in a Member State and whose securities

196. See Consolidated Version of the Treaty on the Functioning of the European Union art. 157(3), Oct. 26, 2012, 2012 ).J. (c 326) 47 ("The European Parliament and the Council, acting in accordance with the ordinary legislative procedure, and after consulting the Economic and Social Committee, shal adopt measues to ensure the application of the principle of equal opportunities and equal treatment of men and women in matters of employment and occupation, including the principle of equal pay for equal work or work of equal value.").

197. See Case 109/88, Union of Commercial \& Clerical Emps., Den. v. Danish Emp'rs' Ass'n ex rel. Danfoss, 1989 E.C.R. 3200, http://curia.europa.eu/juris/showPdf. jsf?text $=\&$ docid $=96004 \&$ pageIndex $=0 \&$ doclang $=$ EN\&mode $=1$ st \&dir $=\& o c c=$ first $\&$ part $=$ $1 \&$ cid $=116499$.

198. See Case C-407/98, Abrahamsson v. Fogelqvist, 2000 E.C.R. I-5562, http:// curia.europa.eu/juris/showPdf.jsf?text $=\&$ docid $=45065 \&$ pageIndex $=0 \&$ doclang $=$ EN\&mo $\mathrm{de}=1$ st \&dir $=\&$ occ $=$ first \&part $=1 \& \mathrm{cid}=431310$.

199. See Case C-409/95, Marschall v. Nordrhein-Westfalen, 1997 E.C.R. I-6383, http://curia.europa.eu/juris/showPdf.jsf?text $=\&$ docid $=43455 \&$ pageIndex $=0 \&$ doclang $=\mathrm{E}$ $\mathrm{N} \&$ mode $=1$ st $\&$ dir $=\&$ occ $=$ first $\&$ part $=1 \&$ cid $=83670$.

200. European Parliament Legislative Resolution, supra note 185, at art. 1. 
are admitted to trading on a regulated market within the meaning of Article 4(1)(14) of Directive 2004/39/EC, in one or more Member States." ${ }^{201}$ The directive excludes small- and medium-sized enterprises (SMEs) - firms that "employ fewer than 250 persons and which have either an annual turnover not exceeding 50 million euro, or an annual balance sheet total not exceeding 43 million euro"202 - from its scope of application. ${ }^{203}$ Article 4(1) provides the meat of the directive, stating,

\begin{abstract}
Member States shall ensure that listed companies in whose boards members of the under-represented sex hold less than 40 per cent of the non-executive director positions adjust their recruitment, including vacancy announcements calling for applications, pre-selection, selection and appointment procedures in such a way that they effectively contribute to the attainment of the said percentage at the latest by 1 January 2020 or at the latest by 1 January 2018 in the case of public undertakings. 204
\end{abstract}

Further, companies are required to select the most qualified candidates from a gender-balanced selection pool and "on the basis of a comparative analysis of the qualifications of each candidate, by applying pre-established, clear, neutrally formulated and unambiguous criteria." 205 If board appointments are elected, companies have to "guarantee gender diversity in the composition of the shortlist of candidates." 206 The objective in all cases is to achieve a representation of at least $40 \% .{ }^{207}$

Article 4(1) also contains the operative provision and states that "Member States shall ensure that ... priority is given to the candidate of the under-represented sex" ceteris paribus "unless an objective assessment, taking account of all criteria specific to the individual candidates, tilts the balance in favour of the candidate of the other sex." ${ }^{208}$ This last portion is capacious and seems to leave interpretive latitude to a selection committee to choose a board member who is not from the underrepresented sex. There is some check on illegitimate activities by the duty to disclose. Member states have to ensure that listed companies disclose, if unsuccessful candidates so request, at least the number and gender of the candidates in the selection pool, "the qualification criteria upon which the selection or appointment was based, the objective comparative assessment of those

201. Id. at art. 2(1).

202. European Comm'n, The New SME Definition: User Guide and Model DECLARATION 13 (2007), http://ec.europa.eu/enterprise/policies/sme/files/sme_definition/ sme_user_guide_en.pdf.

203. European Parliament Legislative Resolution, supra note 185, at recital 18.

204. Id. at art. 4(1).

205. Id. at recital 22.

206. Id. at art. 4(1).

207. Id.

208. Id. 
criteria and, where relevant, the considerations tilting the balance in favour of a candidate of the other sex." 209

Article 4(5) reverses the burden of proof when an unsuccessful candidate is able to establish facts from which it may be presumed that she was as qualified as the successful member from the opposite sex. ${ }^{210}$ In such cases, the company has the burden of proving that it did not act in breach of article 4(1). ${ }^{211}$ This provision is meant to set a minimum standard, and nothing prevents member states from enacting measures that may be more favorable to complainants. Article 4(6a) imposes a requirement on listed companies to inform their shareholders about the directive's provisions and sanctions for noncompliance. ${ }^{212}$

Article 5 requires companies to make commitments at the individual level about achieving gender balance in respect of executive directorships. ${ }^{213}$ Article 5(2) imposes annual reporting obligations on companies to divulge gender representation with details about executive and nonexecutive positions and steps taken to achieve the objectives of Article 4(1). ${ }^{214}$ This information is to be reported in an easily accessible manner on the company's website and in its annual reports. ${ }^{215}$ When the objectives or commitments are not met, the company has to disclose its reasons and any steps it intends to take in the future. ${ }^{216}$ Enforcement of the directive is left to the member states who are required to stipulate "rules on sanctions applicable to infringements of the requirements for an open and transparent procedure ... . [and] take all necessary measures to ensure that they are applied." 217 These sanctions "must be effective, proportionate and dissuasive and shall at least include" fines, judicially ordered nullification or annulment of appointments that are in breach, exclusion from public calls or tenders, and partial exclusion from the award of funding from the European Union's Structural Funds. ${ }^{218}$ Member states are allowed to pursue other actions that are broader than those in the directive as long as they "do not create unjustified gender discrimination or any other form of

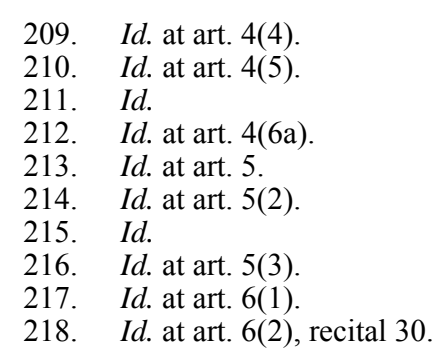


discrimination or hinder the proper functioning of the internal market." 219 The directive is to be implemented by the passage of national law within two years of the European Union adopting the directive. ${ }^{220}$ The procedural requirements in Articles 4(1), (3), (4), and (5) may be suspended by member states that had adopted laws prior to the directive as long as it can be shown that those laws enable the accomplishment of the $40 \%$ representation goal. ${ }^{221}$ This suspension is to be automatically lifted if insufficient progress is made on the diversity front. ${ }^{222}$ The directive deems it to be insufficient progress "if the percentage of the under-represented sex is lower than $30 \%$ by 2017 or by 2015 in the case of public undertakings." 223 Member states have to submit implementation reports to the European Commission by 2017 and every two years thereafter. ${ }^{224}$ In turn, the European Commission is required to submit an evaluation report based on the Member states' reports by 2021 and every two years thereafter. ${ }^{225}$ The European Commission is also required to express a view on extension of the directive's temporal scope and need for extension to nonlisted companies and executive directorships of listed companies. $^{226}$ The directive has a sunset clause and is scheduled to expire in $2028 .{ }^{227}$

The European Parliament adopted the proposed resolution on gender diversity on November 20, 2013, with a vote of 459 in favor to 148 against, with 81 abstentions. ${ }^{228}$ In order to become binding, the directive must also be endorsed by the Council of Ministers and, as a directive, passed into national law of each member state. ${ }^{229}$ Several countries, including Germany, the United Kingdom, the Netherlands, and the Czech Republic have indicated that they intend to block the directive. ${ }^{230}$ However, there has been significant change in the German approach to quota legislation since the September 2013 elections, and the country's

219. Id. at art. 7.

220. Proposal for a Directive, supra note 194, at art. 8(1).

221. Id. at art. 8(3).

222. European Parliament Legislative Resolution, supra note 185, at art. 8(3).

223. Id.

224. Proposal for a Directive, supra note 194, at art. 9(1).

225. Id. at art. 9(3).

226. European Parliament Legislative Resolution, supra note 185, at art. 9(4).

227. Id. at recital 39.

228. Press Release, European Parliament, 40\% of Seats on Company Boards for Women (Nov. 20, 2013), http:/www.europarl.europa.eu/news/en/news-room/content/ 20131118ipr25532/html/40-of-seats-on-company-boards-for-women; Directive.

229. Id.

230. E.g., Newsletters Get Women on Board-Issue No. 3, GET WOMEN ON BOARD, http://get-women-on-board.eu/en/ct/8-newsletters-get-women-on-board-issue-\%233 (last visited Mar. 30, 2015). 
opposition to the directive is likely to falter. ${ }^{231}$ The directive is at the stage of first reading in the Council of the European Union, ${ }^{232}$ and after two debates, the Council has not been able to "reach a general approach on the directive. ${ }^{233}$ The directive requires the support of a double majority of members in order to pass into European law. ${ }^{234}$ After the first reading on December 9, 2013, the Council has yet to take a first reading position. ${ }^{235}$

In a speech after the directive passed the European Parliament, Reding referenced a social justice based justification for diversity: "The Parliament has made the first cracks in the glass ceiling that continues to bar female talent from the top jobs."236 This is supported in much of the rhetoric around the directive. Although several arguments are canvassed-talent pool, improved governance, business case, and avoidance of group thinkit appears that the dominant reason for the European Union directive is social justice, particularly full economic participation of women in democracy. This portrayal of gender equality as having stages of which economic participation is the current struggle situates the directive within the gender equality social justice narrative.

\section{The United Kingdom}

Lord Davies' government-commissioned report Women on Boards provided the most significant impetus for the gender diversity agenda in the United Kingdom. ${ }^{237}$ The report's normative commitment is predicated on the "business case" for greater representation of women on corporate

231. The newly elected German coalition government has agreed to implement a $30 \%$ quota on supervisory boards with draft legislation currently with various ministries for comment. See, e.g., MacLaughlin, supra note 142.

232. Procedure File: 2012/0299(COD), Gender Balance Among Non-Executive Directors of Companies Listed on Stock Exchanges, EuR. PARLIAMENT, http://www. europarl.europa.eu/oeil/popups/ficheprocedure.do?reference=2012/0299(COD)\&l=en (last updated Jan. 22, 2015).

233. European Parliament, Debate in Council 2012/0299(COD)-11/12/2014, http://www. europarl.europa.eu/oeil/popups/summary.do? $\mathrm{id}=1371523 \& \mathrm{t}=\mathrm{e} \& \mathrm{l}=\mathrm{en}$.

234. European Parliament, http://www.europarl.europa.eu/aboutparliament/en/0081 f4b3c7/Law-making-procedures-in-detail.html (last visited Mar. 30, 2015).

235. Procedure File: 2012/0299(COD), Gender Balance Among Non-Executive Directors of Companies Listed on Stock Exchanges, supra note 232.

236. Christina Vasilaki, MEPs Backed Quotas For Women on Boards, NEw EuR. (Nov. 20, 2013, 1:41 PM), http://www.neurope.eu/article/meps-backed-quotas-womenboards.

237. See LORD DAVIES OF ABERSOCH, supra note 4, at 3. 
boards being "clear." 238 It recommended that listed companies in the FTSE 100 pledge their support for a target of $25 \%$ women directors by 2015 and that smaller companies in the FTSE 350 set their own aspirational targets to be achieved by 2013 and $2015 .{ }^{239}$ Lord Davies' ten recommendations include increased investor advocacy and work on the female corporate "pipeline." ${ }^{240}$ While preserving the primary role for businesses, Lord Davies observed that government "must reserve the right to introduce more prescriptive alternatives if the recommended businessled approach does not achieve significant change." ${ }^{241}$ As important as Lord Davies' report is for principle, the actualization of the diversity agenda would require pragmatic operational steps. Perhaps the most crucial in this regard was the adoption of a voluntary code of conduct for executive search firms committing to include one-third of the positions on long lists for board appointments in favor of women. ${ }^{242}$

It is noteworthy that even before the release of Lord Davies' report, the United Kingdom Corporate Governance Code (CGC) was amended in 2010 to include reference to diversity objectives. Section B.2's supporting principle provides that "[t]he search for board candidates should be conducted, and appointments made, on merit, against objective criteria and with due regard for the benefits of diversity on the board, including gender." ${ }^{243}$ Following Lord Davies' recommendation of further amendments, the Financial Reporting Council (FRC) called for consultation on two of the recommendations. ${ }^{244}$ After consultation between May and July 2011, the FRC announced in October 2011 that it had determined to include the recommendations in the CGC, albeit using a slightly revised form of words. $^{245}$ The process leading up to this change also indicates the priorities of the discourse. The consultation was not merely an exercise in receiving practical feedback; it was a de facto vote on the measures

238. Id.

239. Id. at 4.

240. See id. at $18-20$.

241. David Katz, Developments Regarding Gender Diversity on Public Boards, HARV. L. SCH. F. ON CORP. GOVERnANCE \& Fin. Reg. (Nov. 12, 2013, 9:23 AM), https://blogs.law.harvard.edu/corpgov/2013/11/12/developments-regarding-gender-diversityon-public-boards/.

242. See Voluntary Code of Conduct for Executive Search Firms, MWM CONSUlting (April 2013), http://www.mwmconsulting.com/wp-content/uploads/2012/07/ Voluntary-Code-of-Conduct-for-Search-Firms.pdf.

243. Fin. Reporting Council, The UK Corporate Governance Code 12 (2012) [hereinafter UK CORPORATE GOVERNANCE CODE], https://www.frc.org.uk/Our-Work/ Publications/Corporate-Governance/UK-Corporate-Governance-Code-September-2012.aspx.

244. Fin. Reporting Council, Feedback Statement: Gender Diversity on BOARDS 1 (2011), https://www.frc.org.uk/FRC-Documents/FRC/Feedback-Statement-GenderDiversity-on-Boards.aspx.

245. Id. 
suggested by Lord Davies. When the FRC report states the course of action it has chosen, it notes that this course is "[i]n accordance with the views of the vast majority of respondents." 246 The FRC also records that some respondents indicated that diversity should be considered more broadly than gender because of "the benefit of having foreign nationals on the board when a company is entering new geographical markets." 247 This comment demonstrates that the business community considers gender diversity through an instrumental lens. Even when ethnic diversity is mentioned it is as a transient resource set in service of corporate financial goals and not in connection with any concerns for representation. The weight this comment is given by the FRC demonstrates a key difference between business case arguments and social justice arguments. Business case arguments measure the instrumental value of changes and suggest action on the most valuable of these potential changes. The government is in this context an advisor and encourager, providing information and making arguments regarding the effect of the business case on the broader economy. Social justice arguments accept the intrinsic value of certain persons, and in this context the government fulfills the role of creating a uniform point in time at which all companies must take action such that no company is unfairly advantaged or disadvantageddepending on whether the changes have positive or negative economic impacts. ${ }^{248}$

Following the consultation period, two further amendments were made and the amended CGC was published in September 2012, including provision B.2.4:

\begin{abstract}
A separate section of the annual report should describe the work of the nomination committee, including the process it has used in relation to board appointments. This section should include a description of the board's policy on diversity, including gender, any measurable objectives that it has set for implementing the policy, and progress on achieving the objectives. 249
\end{abstract}

This section reflects the United Kingdom's focus on voluntary initiatives rather than compulsory requirements. It also reflects the belief in merit as

246. Id.

247. Id. at 3 .

248. This is similar to the effect of the Civil Rights Act of 1964, Pub. L. No. 88-352, 78 Stat. 241, 243 (1964), on restaurants, for example.

249. UK CORPORATE GOVERNANCE CODE, supra note 243, at 13. 
a value in itself and its acceptance of a potentially lengthy time frame for the increase in the number of women on boards. ${ }^{250}$

It should come as no surprise that the United Kingdom has been opposed to the introduction of quotas at the European Union level. Its response to the European Union consultation on gender diversity argued that only business-initiated diversity measures are likely to be sustainable because "[t]o bring about real change in this area that is sustainable and long-term, companies need to understand and believe that diverse boards are better boards," which would create "a business environment where women can take their seat on merit and without the spectre of tokenism."251 This argument also presumes a dichotomy of merit and quotas-premised on the assumption that current appointment practices are adequately merit-based. In arguing that businesses should be given the opportunity to initiate action, the United Kingdom submission cited empirical research that diverse boards are more effective, that "women make around $70 \%$ of consumer purchasing decisions," and that there is a need for "fresh or different perspectives" in order to prevent "group-think." 252 These arguments, although cited separately, come together to form a business case for gender diversity on boards. ${ }^{253}$ This business case appears to be the primary motivator for the United Kingdom government in their support of increased gender diversity on boards. As such, the government's submission explicitly outlines that the "overt emphasis placed on the economic importance of diverse boards" has drawn media attention and led to negative publicity for companies that are not making efforts to ensure more women are appointed to their boards. ${ }^{254}$

Opposition to European Union board quotas is deep rooted in the United Kingdom. For instance, the House of Lords Internal Market, Infrastructure, and Employment subcommittee issued a report on July 9, 2012 opposing the introduction of a quota on subsidiarity grounds, following evidence from interested parties including businesses. ${ }^{255}$ The argument is that member states were best able to deal with the issue of gender diversity on

250. See id. at 12.

251. Gov't Equals. Office, supra note 193.

252. Id.

253. LORD DAVIES OF ABERSOCH, supra note 4, at 3.

254. Gov't Equals. Office, supra note 193.

255. For details of the seven business leaders called to speak to the committee on Monday July 9, 2012, see Women on Boards: Supply or Demand?, PARLIAMENT (July 9, 2012), http://www.parliament.uk/business/committees/committees-a-z/lords-select/euinternal-market-sub-committee-b/news/gender-balance-business-leaders-and-headhunters/. 
boards without European Union intervention. ${ }^{256}$ However, the report conceded that " $[t]$ he figures strongly indicate that opportunities for progression are not shared equitably between men and women, and it is absolutely vital that this issue is addressed." ${ }^{257}$ In parliamentary debate on the report and the content of the reasoned opinion to be submitted to the European Union, Baroness O'Cathain, the subcommittee's chairperson, stated that the aim of increasing the number of women on boards was to "ensure that all of the talent in our jobs market is used to the full, regardless of gender, without the need for imposed quotas."258 Opposition to quotas was widespread. Baroness Bottomley argued that a quota would be anathema to British culture:

\begin{abstract}
A quota is alien to the British way of thinking. We believe in voluntary principles, in persuasion, in best practice and a bit of naming and shaming. Our approach is a voluntary one wherever possible and quotas offend. A target, a goal, an objective, but not a quota. 259
\end{abstract}

Interestingly, Baroness O'Cathain acknowledged that the subcommittee "cannot find evidence that there is a direct link between putting more women on boards as non-executive directors and better financial performance by the company itself." ${ }^{260}$ In the same week, on January 7, 2013, the House of Commons also debated a submission on the European Union proposed directive. ${ }^{261}$ There, Matthew Hancock, the then Parliamentary Under-Secretary of State for Skills, claimed, "Crucially, we are following a voluntary business-led approach, because the research shows that diverse boards are better boards," 262 evidencing lack of clarity about the real reason for supporting board diversity.

Against this climate of hostility to quotas and freedom for businesses to set aspirational goals, the United Kingdom has witnessed dramatic positive change. Whereas only $9.4 \%$ of directors in the FTSE 100 were

256. See European Union Committee, Women on BoArds, Report, 2012-13, H.L. 58, at 14 (U.K.), http://www.publications.parliament.uk/pa/ld201213/ldselect/ldeucom/ 58/58.pdf.

257. Id. at 11 .

258. Lords Debate Women on Boards Report, PARLIAMENT (Nov. 13, 2012), http://www.parliament.uk/business/committees/committees-a-z/lords-select/eu—internalmarket-sub-committee-b/news/gender-balance-debate.

259. 742 PARL. Deb., H.L. (6th ser.) (2013) 344 (U.K.).

260. Id. at 343 .

261. 556 PARL. Deb., H.C. (6th ser.) (2013) (U.K.).

262. Id. at 54 . 
women in 2004, the corresponding figure for 2010 was $12.5 \%{ }^{263}$ Following the heightened attention to the issue after Lord Davies' report and the FRC amendments, the percentage of female directors rose from $12.5 \%$ in 2010 to $20.7 \%$ in $2014 .{ }^{264}$ That is more than double the improvement in less than half the time. There are now no all-male FTSE 100 boards after Glencore PLC appointed Patrice Merrin as a director in June 2014. ${ }^{265}$ Given the comments cited above about the British preference for voluntary measures, it may be that British businesses are more responsive to suggestion than to sanction, especially in the shadow of a legislative quota from the European Union.

Since October 1, 2013, United Kingdom companies have been subjected to new requirements to submit annual strategic reports and directors' reports. ${ }^{266}$ Section 414A of the Companies Act requires all companies that are not subject to the exemption for small companies to prepare a strategic report. ${ }^{267}$ The FRC has provided guidance on preparing the strategic report. ${ }^{268}$ It expects the report to "provide shareholders ... with information that will enable them to assess how the directors have performed their duty to promote the success of the company." 269 Importantly, the new provision requires disclosure of "(i) the number of persons of each sex who were directors of the company; (ii) the number of persons of each sex who were senior managers of the company ... and (iii) the number of persons of each sex who were employees of the company." 270 A "senior manager" is defined as an employee of the company who "has responsibility for planning, directing or controlling the activities of the company, or a strategically significant part of the company." 271 It is an offense for directors to fail "to take all reasonable steps for securing compliance." ${ }^{272}$ If found guilty, a director must pay a

263. LORD DAVIES OF ABERSOCH, supra note 4, at 11.

264. The Female FTSE Board Report 2014, CranfiEld U. Sch. MGMt. (Mar. 26, 2014), http://www.som.cranfield.ac.uk/som/p21687/Knowledge-Interchange/ManagementThemes/Leadership/Leadership-News/The-Female-FTSE-Board-Report-2014.

265. Sean Farrell, Glencore, Last All-Male FTSE 100 Board, Appoints Patrice Merrin as Director, GuARDiAN (June 26, 2014, 4:39 PM), http://www.theguardian. $\mathrm{com} /$ business/2014/jun/26/glencore-male-board-patrice-merrin-woman.

266. See Companies Act 2006 (Strategic Report and Directors' Report) Regulations, 2013, S.I. 2013/1970 (U.K.).

267. Id. § 414A, $\uparrow 1$.

268. See Fin. Reporting Council, Guidance on the Strategic Report (2014), https://www.frc.org.uk/Our-Work/Publications/Accounting-and-Reporting-Policy/Guidance-onthe-Strategic-Report.pdf.

269. Id. at 14.

270. Companies Act 2006 (Strategic Report and Directors' Report) Regulations, 2013, S.I. 2013/1970, § 414C, 97 (U.K.).

271. Id. at $\S 414 \mathrm{C}$, 99.

272. Id. at $\S 414 \mathrm{~A}$, 9 5(b). 
fine. ${ }^{273}$ Section 463 also imposes liability on directors to compensate the company if any loss results because of any untrue or misleading statement in the strategic report, the director's remuneration report, or the director's report. $^{274}$

The United Kingdom's record may be affected by Scottish developments because the government there has stated that "this issue is not just about fairness or giving women opportunities. ... [G]reater diversity on boards leads to better governance. If a board better reflects the people it serves, it will be better equipped to make decisions affecting them, and so improve its performance." 275 Significantly, Scottish ministers have asked the United Kingdom government to transfer legislative power so that mandatory quotas may be introduced in Scotland. ${ }^{276}$

\section{Australia}

Recent figures show that $19.3 \%$ of directors of ASX 200 firms are female. ${ }^{277}$ The proportion declines further in the ASX 500 and smaller listed firms. ${ }^{278}$ Although there appears to be limited appetite for intervention on the part of the government, there is growing media attention to diversity and several high profile figures have expressed support for government action by way of board gender quotas. Federal Sex Discrimination Commissioner Liz Broderick, former GovernorGeneral Quentin Bryce, and Treasurer Joe Hockey have all spoken in support of quotas. ${ }^{279}$ In an article for the Australian Financial Review, Liz Broderick argued that "[g]etting more women onto boards ... is not just about gender equity. It's also about our desire to remain internationally competitive. No country, industry or organisation can

273. Id. at $\S 414 \mathrm{~A}, \boldsymbol{9} 6(\mathrm{a})$.

274. Id. at $\S 463$, consequential amend. 17.

275. Women on Board: Quality Through Diversity, Scottish Government Consultation on the Introduction of Gender Quotas on Public Boards, SCOT. Gov'T, http://www. scotland.gov.uk/Publications/2014/04/1438/296931 (last updated May 2, 2014).

276. See id.

277. See Statistics, supra note 25.

278. For example in 2012, women held $12.3 \%$ of ASX 200 directorships and $9.2 \%$ of ASX 500 directorships. EQUAL OPPORTUNITY FOR WOMEN IN THE WORKPLACE AGENCY, AUSTl. GOV'T, AUSTRALIAN CENSUS OF WOMEN IN LEADERSHIP (2012), https://www.wgea. gov.au/sites/default/files/2012_CENSUS\%20REPORT.pdf.

279. Christine Milne, Why I Changed My Mind About Quotas for Women on Boards, MAMAMIA (Apr. 11, 2013, 7:10 AM), http://www.mamamia.com.au/news/christinemilne-quotas-for-women-on-boards/. 
afford to waste the skills of more than half its population." ${ }^{280}$ Broderick's focus on the national talent pool reflects that of the Norwegian government. Speaking on the ABC program $Q \& A$, Joe Hockey, then Shadow Treasurer with responsibility for corporate governance issues, commented, "I just don't understand how you can claim as a director of a company that all wisdom and knowledge lies in the hands of men only."281 He went on to claim that "[q]uotas must be a last resort but the current situation is unacceptable." 282 However, Tony Abbott, then leader of the opposition and current Prime Minister, has "been cool on quotas. If women are given the chance to show their abilities they will get places on their merits." 283

In March 2013, leader of the Australian Greens Party, Senator Christine Milne, moved that the Senate "calls on the Government to legislate to ensure ASX 200 companies have a minimum of 40 per cent female board directors within the next 5 years." 284 Only the nine members of the Australian Greens Party voted in favor of the motion, and only one senator sought to make a statement on their vote. ${ }^{285}$ Senator Michaelia Cash, of the Liberal National Party, made a short statement defending her party's opposition to the motion, arguing that quotas undermine merit:

$[\mathrm{H}]$ igh-level appointments of women should recognise merit and excellence rather than be based on some unilateral quota which could be intended or interpreted to placate women rather than promote excellence and advance the cause of Australian women.... [T] he appointment of women ... for reasons other than merit and excellence could be counterproductive and work against the long-term interests of women. 286

Amidst these political debates, the gender diversity movement is gaining traction at the business level. For instance, the Australian Institute of Company Directors has instituted a mentorship program for women that links potential female board members with experienced-male or

280. Elizabeth Broderick, Mandatory Quotas May Be Needed on Boards, AUSTL. FIN.

281. Lenore Taylor \& Kirsty Needham, Abbott Breaks with Hockey over Board Quotas for Women, SYDNEY MORNING HERALD (Mar. 9, 2011), http://www.smh.com.au/ national/abbott-breaks-with-hockey-over-board-quotas-for-women-20110308-1bmoi.html \#ixzz35QXuso2K.

282. Id.

283. Id.

284. Cth, Parliamentary Debates, Senate, 13 Mar. 2013, 1616 (Christine Milne, Senator

$\&$ Leader of the Australian Greens) (Austl.).

285. Id.

286. Cth, Parliamentary Debates, Senate, 13 Mar. 2013, 1616 (Michaelia Cash, Senator) (Austl.). 
female-directors and focuses on both mentoring and securing a board role for the mentee. ${ }^{287}$

The most significant instrument in the legal arsenal is the ASX comply or explain regime on gender targets through its CGC. These gender diversity requirements were explicitly premised upon there being a positive contribution to firm performance; the ASX cited the Catalyst and Reibey studies in support. ${ }^{288}$ The ASX also states in commentary that its reasons for recommending that listed companies have a diversity policy and report on their diversity progress include the belief that "the promotion of gender diversity can broaden the pool for recruitment of high quality employees, enhance employee retention, foster a closer connection with and better understanding of customers, and improve corporate image and reputation."289

The diversity recommendations were originally issued in 2010 and are applicable to listed companies for the reporting period commencing on January 1, 2011; they have been amended in the third edition published in $2014 .^{290}$ Recommendation 1.5 of the Code requires a listed company to "have a diversity policy which includes requirements for the board or a relevant committee of the board to set measurable objectives for achieving gender diversity and to assess annually both the objectives and the entity's progress in achieving them." 291 The company is required to disclose the diversity policy or a summary of the policy on its website. ${ }^{292}$ This policy might provide a description of the "corporate benefits of diversity" and the "importance of being able to attract, retain and motivate employees from the widest possible pool of available talent." ${ }^{293}$ In order to provide incentives for the policy to translate from mere talk into concrete action, the ASX Corporate Governance Council suggests that the diversity policy could set "key performance indicators for senior executives" that are capable of being measured against diversity objectives. ${ }^{294}$ Importantly, it suggests that executive compensation be "link[ed] . . to the achievement

287. See Chairman's Mentoring Program, Austl. InST. OF COMPANY DiRECTORS, http://www.companydirectors.com.au/Director-Resource-Centre/Governance-and-DirectorIssues/Board-Diversity/Mentoring-Programs (last visited Mar. 30, 2015).

288. See ASX CORPORATE GOVERNANCE COUNCIL, supra note 152, at $11 \mathrm{n} .17$ (citing CARTER \& WAGNER, supra note 82; REIBEy INST., ASX 500-WOMEN LEADERS (2011)).

289. Id. at 11 .

290. Id. at 2 .

291. Id. at 11.

292. Id.

293. Id. at 13.

294. Id. 
of those [diversity] objectives." 295 In addition, the recommendation requires disclosure of "the measurable objectives for achieving gender diversity set by the board ... in accordance with the entity's diversity policy and its progress towards achieving them." ${ }^{296}$ Companies also have to make either of the following disclosures: the gender proportions of board positions, senior executives, and all employees, or if applicable, the "Gender Equality Indicators" under the 2012 Workplace Gender Equality Act. ${ }^{297}$ In its explanatory commentary, the ASX suggests the measurable objectives could include benchmarks for "achieving specific numerical targets (eg, a target percentage) for the proportion of women employed by the organisation generally, in senior executive roles and on the board within a specified timeframe." ${ }^{298}$ It also recommends that any changes to the measurable objectives should be disclosed by the company. ${ }^{299}$ In addition, the diversity policy could clearly express the company's commitment to diversity at all levels, include references to diversity across age, ethnicity, and other aspects, and provide structural protections against discrimination in recruitment and selection. ${ }^{300}$

From a structural perspective, it is significant that the diversity recommendation forms part of Principle 1: "Lay solid foundations for management and oversight." ${ }^{301}$ The recommendations gain coercive force through ASX Listing Rule 4.10.3, which requires that companies disclose the extent to which they have complied with the best practice recommendations and to explain any discrepancies. ${ }^{302}$

In addition to the ASX requirements, the Workplace Gender Equality Act (WGEA) requires companies to report a variety of "gender equality indicators" including the "gender composition of governing bodies of relevant employers." 303 The purposes of the WGEA include an aim "to improve the productivity and competitiveness of Australian business through the advancement of gender equality in employment and in the workplace." 304 The risk of business case arguments such as these can be

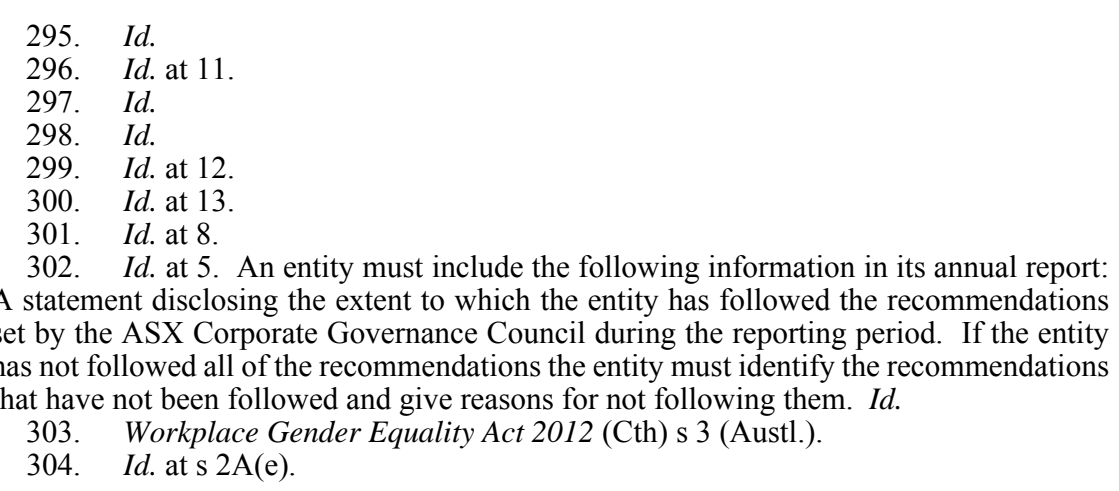


seen in recent coalition government moves to reduce reporting requirements to apply only to companies with over 1000 employees instead of to companies with over 100 employees for reasons of efficiency. ${ }^{305}$ However, these suggestions faced significant criticism $^{306}$ and the coalition finally announced that there would be no change to the threshold. ${ }^{307}$

In the three years since the adoption of the diversity recommendations, the Australian landscape stands in contrast to the positive changes witnessed in the United Kingdom and many other European countries. Rather, the evidence suggests that there is considerable rhetoric and noise but little in the way of actual results. A study conducted by KPMG analyzing a large sample of Australian companies showed a very high rate of compliance on diversity policies. ${ }^{308}$ For companies reporting in 2013, $98 \%$ of the 600 companies sampled had a diversity policy or provided an explanation for not having one. ${ }^{309}$ In the explanatory commentary, companies listed a number of benefits from their adoption of a diversity policy, including "enhanced corporate performance, reputation and shareholder value," "maximization of the talent potential," and "access to different perspectives, ideas and innovative approaches leading to better decision making and business outcomes." ${ }^{310}$ In the sample of 198 companies within the ASX 200 group, measurable objectives stipulated by Recommendation $1.5(\mathrm{c})$ had been established by $86 \%{ }^{311}$ The corresponding figure for the 200 companies sampled in the ASX 201-500 group was $56 \%$, and for the 200 companies in the ASX 501+ sample was $29 \%{ }^{312}$ There was considerable variability in the actual content of the measurable objectives with one end of the spectrum being actual numerical targets to increase diversity and the other end being statements, such as to

305. See Leanne Mezrani, Women's Coalition Fights To Keep Gender Reporting, LAW. WKLY. (Mar. 18, 2014), http://www.lawyersweekly.com.au/news/women-s-coalitionfights-to-keep-gender-reporting.

306. See id.; Gender Reporting Requirements Not 'Red Tape,' WOMEN ON BOARDS (Mar. 18, 2014), http://www.womenonboards.org.au/news/2014/media140318-coalition.htm.

307. See Minimum Standard for Gender Equality, SENATOR ERIC ABETz (Mar. 25,

2014, 5:19 PM), https://abetz.com.au/news/minimum-standard-for-gender-equality.

308. See KPMG, supra note 28.

309. Id. at 11 .

310. Id. at 16.

311. Id. at 21.

312. Id. at 21-22. 
[s]upport management globally in understanding the benefits of flexible working arrangements that support both business needs and a family friendly workplace; [i]mplement global sourcing, recruitment and selection principles to further support gender diversity; [e]xplore the range of existing diversity through an employee survey; [e]stablish a diversity scorecard; [and] [u]ndertake the analysis required to develop appropriate targets. 313

It is clear that this category of measurable objective is an oxymoron and companies are finding creative ways to tick the box without really committing to the diversity goal. On a slightly positive note, the KPMG study shows that the average number of women on the board of companies in the ASX 200 sample increased by $3 \%$ from $15 \%$ in 2012 to $18 \%$ in 2013. ${ }^{314}$ For companies in the ASX 201-500 group, the average remained at $10 \%,{ }^{315}$ whereas for the ASX 501+ group, it rose from $8 \%$ in 2012 to $9 \%$ in $2013 .^{316}$

BlackRock Investment Management (Australia) Limited conducted a study of diversity reporting and concluded that $65 \%$ of diversity disclosures are "perfunctory" and "most organisations are applying a largely "minimal standard' mindset." 317 It also found that some of the measurable objectives listed by companies were "not possible to measure."318 The study found that the number of senior executive positions held by women had not kept pace with the increase in their holdings of board positions and that the lack of a consistent definition as to what constitutes a "senior executive" made the ASX recommendations difficult to measure for compliance. ${ }^{319}$

\section{E. The United States}

The SEC issued Proxy Disclosure Enhancements in $2009^{320}$ following a period of consultation about the need for action to address the low levels of women's representation on corporate boards. The SEC noted that many respondents believed that diversity information is important to investors and that it would equip them to make more "informed" decisions by providing "information on corporate culture and governance practices." 321 Commenters believed that "there appears to be a meaningful relationship

313. Id. at 24

314. Id. at 27.

315. Id. at 28 .

316. Id. at 29.

317. See BLACKROCK, supra note 18 , at 3.

318. Id.

319. Id. at 4 .

320. Proxy Disclosure Enhancements, Exchange Act Release Nos. 33,9089; 34,61175, Investment Company Act Release No. 29,092, 74 Fed. Reg. 68,334 (Dec. 23, 2009) (to be codified at 17 C.F.R. $\$ \S 229,239,240,249,274)$

321. Id. at 68,343 . 
between diverse boards and improved corporate financial performance, and that diverse boards can help companies more effectively recruit talent and retain staff." ${ }^{322}$ The new rules were adopted as amendments to Item 407 (c) of Regulation S-K, which governs disclosure obligations. ${ }^{323}$ Crucially, the SEC chose not to define diversity because of a belief that "companies should be allowed to define diversity in ways that they consider appropriate" because while some "may conceptualize diversity expansively to include differences of viewpoint, professional experience, education, skill and other individual qualities and attributes that contribute to board heterogeneity," other companies might have a narrower view focusing on "race, gender and national origin." 324 The agency also conceded that the rules were "not intended to steer behavior." 325

Under the rules, companies are required to disclose "whether, and if so how, the nominating committee (or the board) considers diversity in identifying nominees for director." 326 If the company has a diversity policy, it has to "describe how this policy is implemented, as well as how the nominating committee (or the board) assesses the effectiveness of its policy." 327 Notably, the SEC does not mandate that companies consider diversity in appointments or that they have a policy, only that they disclose whether they do so or not. ${ }^{328}$

It is not surprising that progress has been very slow and that the SEC's disclosure provision appears to be largely superfluous. One study of Fortune 50 companies documented that $60 \%$ of companies were not in compliance with the SEC rules. ${ }^{329}$

\section{F. Spain}

Spain was the second nation to legislate a quota for female board members. In March 2007, the Spanish government announced that publicly traded companies with over 250 employees would be required to have at

322. Id

323. Id.

324. Id. at 68,344

325. Id. at 68,355 .

326. Id. at 68,364 .

327. Id.

328. See id.

329. See Smallman, supra note 19 , at 817. 
least $40 \%$ female directors within eight years. ${ }^{330}$ The Gender Equality Act, enacted on March 22, 2007, by the Spanish Congress, brought together a variety of gender equity measures by incorporating several European directives including Directive 2002/73/EC and Directive 2004/ 113/EC and introducing a board quota. ${ }^{331}$ The legislative program was completed in December 2007 when the Strategic Plan of Equal Opportunities 2008-2011 was approved. ${ }^{332}$ When the Spanish socialist party formed a minority government after the March 2008 election, they further consolidated the legislation by creating a "Ministry of Equality" in $2008 .{ }^{333}$

The Spanish board-gender-diversity debate is part of a wider conversation about antidiscrimination and social justice. Notably, at the time the quota was introduced, only about $6 \%$ of directors were female and action was seen to be necessary. ${ }^{334}$ Article 1 of the Gender Equality Act explicitly states that "[t]he purpose of this Act is to ensure equal treatment and opportunities for women and men ... so as to build a more democratic, fair and solidary society." 335 The preamble acknowledges that

\begin{abstract}
higher female unemployment, the still scant presence of women in positions of political, social, cultural and economic responsibility, or the problems of reconciling personal, working and family life stand as evidence that the attainment of full, effective equality between women and men . . . is even today an unfinished task, whose completion calls for further legal instruments. 336
\end{abstract}

The statute establishes a gender quota for the boards of corporations with more than 250 employees. ${ }^{337}$ Article 75 provides that relevant companies "will endeavour to include a sufficient number of women on their boards of directors to reach a balanced presence of women and men within eight years of the entry into effect of this Act," 338 and "balanced presence" is defined as between $40 \%$ and $60 \%$ of each gender. ${ }^{339}$

330. Constitutional Act 3/2007 of 22 March for Effective Equality Between Women and Men (B.O.E. 2007, 71) (Spain).

331. Id.

332. ORg. For ECON. CO-OPERATION \& Dev., Women, GOVERnMENT AND POLICY

MAKING IN OECD COUNTRIES: FOSTERING DIVERSITY FOR INCLUSIVE GROWTH 103 (2014).

333. Emanuela lombardo, European Parliament, SPanish Policy on Gender

EQuality: ReleVANT CuRRENT LegisLation AND Policies 5 (2009).

334. Credit Suisse, Gender Diversity and Corporate Performance 25 fig. 21

(2012), https://www.credit-suisse.com/newsletter/doc/gender_diversity.pdf.

335. Constitutional Act 3/2007 of 22 March for Effective Equality Between Women and Men art. 1 (B.O.E. 2007, 71) (Spain).

336. Id.at pmbl.

337. Id. at art. 45(2).

338. Id. at art. 75 .

339. Id. at art. 78(2). 
The law entered into force on March 24, 2007, and companies were given eight years to comply. ${ }^{340}$ It is significant that despite the legal mandate and contrary to the United Kingdom that through soft means seems on track to meet its $25 \%$ target by the end of $2015,{ }^{341}$ Spain is unlikely to meet its $40 \%$ quota by March 2015 . In October 2012, only $12.3 \%$ of board members were female in Spain. ${ }^{342}$ A major contributor to tardy implementation may be the lack of sanctions for noncompliance. Unlike Norway, in Spain compliance is incentivized by a "corporate equality mark" available only to compliant companies. ${ }^{343}$

In addition to the government's quota legislation, the Spanish National Stock Exchange Commission issued a Good Governance Code in May $2006 .{ }^{344}$ The code outlines a series of recommendations, including Recommendation 15 on the gender composition of boards of directors to be implemented on a comply or explain basis. ${ }^{345}$ This recommendation became a legal obligation on March 20,2013, and requires more detailed annual corporate governance reports. ${ }^{346}$ The National Securities Market Commission then issued Circular Resolution 4/2013 on June 12, 2013, which provided more detail of the content and structure of these required reports, including the number of women on the boards in the past four years, and any effective measures to promote gender equality. ${ }^{347}$

340. Guijarro \& Abril, supra note 98, at 98.

341. European Comm'n, National FactsheEt: Gender Balance in BoARds: UNITED KINGDOM 3 (2013), http://ec.europa.eu/justice/gender-equality/files/womenonboards/ womenonboards-factsheet-uk_en.pdf.

342. European Comm’n, National FactsheEt: Gender Balance in BoARds: SPAIN 3 (2013), http://ec.europa.eu/justice/gender-equality/files/womenonboards/womenonboards -factsheet-es_en.pdf.

343. Constitutional Act 3/2007 of 22 March for Effective Equality Between Women and Men art. 50 (B.O.E. 2007, 71) (Spain).

344. See European Corporate Governance Inst., Report of the Special Working Group on the GoOd Governance OF Listed Companies (2006), http:// www.ecgi.org/codes/documents/unified_code_may2006_en.pdf.

345. See id. at $41-64$.

346. See Order ECC/461/2013 of 20 March, Approving the Content and Structure of the Annual Corporate Governance Report (B.O.E. 2013, 71) (Spain).

347. See Hogan Lovells \& Luis Enrique de la Villa, Women on Boards-Spain, LEXOLOGY (Mar. 13, 2014), http://www.lexology.com/library/detail.aspx?g=64f4e 057cf73-4dfb-8a94-498763033381. 


\section{G. Other Countries}

Belgium, ${ }^{348}$ France, ${ }^{349}$ Iceland, ${ }^{350}$ India, ${ }^{351}$ Italy, ${ }^{352}$ Malaysia, ${ }^{353}$ Netherlands, ${ }^{354}$ Slovenia, ${ }^{355}$ Spain, ${ }^{356}$ and the United Arab Emirates ${ }^{357}$ each have implemented some form of gender quota for corporate boards. An even greater number of countries have implemented quotas only applicable to state-owned enterprises, some of which predate the Norwegian legislation. ${ }^{358}$ Many countries are developing alternate means of promoting gender diversity on corporate boards.

348. See Loi modifiant la loi du 21 mars 1991 portant réforme de certaines enterprises publiques économiques, le Code des sociétés et la loi du 19 avril 2002 relative à la rationalisation du fonctionnement et de la gestion de la Loterie Nationale afin de garantir la présence des femmes dans le conseil d'administration des enterprises publiques autonomes, des sociétés cotées et de la Loterie Nationale [Law Modifying the Law of March 21, 1991 Reforming Certain Public Economic Enterprises, the Belgian Company Code and the Act of April 19, 2002 on the Rationalization of the Function and Management of a National Lottery to Ensure the Presence of Women on the Board of Autonomous Public Enterprises, Listed Companies, and the National Lottery] of June 16, 2011, MoNiTEUR BELGE [M.B.] [Official Gazette of Belgium], Sept. 14, 2011, 2d ed.

349. See Loi 2011-103 du 27 janvier 2011 relative à la représentation équilibrée des femmes et des hommes au sein des conseils d'administration et de surveillance et à l'égalité professionnelle [Law 2011-103 of 27 January 2011 on the Balanced Representation of Women and Men on Boards of Directors, Supervisory Boards, and Professional Equality],

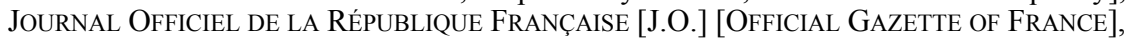
Jan. 28, 2011, p. 1680

350. See Lög um hlutafélög, nr. 2, 30. janúar 1995 as amended by Lög um breytingu á lögum um hlutafélög og lögum um einkahlutafélög. (eignarhald, kynjahlutföll og starfandi stjórnarformenn), nr. 13, 8. mars 2010 (Ice.).

351. See The Companies Act, 2013, No. 18, Acts of Parliament, 2013 (India).

352. See Legge 12 luglio 2011, n. 120, in G.U. July 28, 2011, n. 174 (It.).

353. See DelOITTE, supra note 154 , at 7.

354. See Wet van 6 juni 2011 tot wijziging van boek 2 van het Burgerlijk Wetboek in verband met de aanpassing van regels over bestuur en toezicht in naamloze en besloten vennootschappen [Act of June 6, 2011 To Amend Book 2 of the Civil Code in Connection with the Adjustment to Rules on Management and Control in Public and Private Companies], Stb. 2011 (Neth.).

355. See Uredba o kriterijih za upoštevanje načela uravnoežene zastopanosti spolov [Government Regulation No. 103/04 on Criteria for Respecting the Principle of Gender Balanced Representation], Uradni List RS, No. 103.04 (Slovn.).

356. See Constitutional Act 3/2007 of 22 March for Effective Equality Between Women and Men (B.O.E. 2007, 71) (Spain).

357. See Lianne Gutcher, Women on Every UAE Board, Rules Cabinet, NATIONAL (Dec. 10, 2012), http://www.thenational.ae/business/industry-insights/economics/womenon-every-uae-board-rules-cabinet.

358. See supra note 142 . 


\section{Belgium}

In Belgium, a quota of 33\% was introduced for publicly traded and state-owned enterprises effective September 14, 2011.359 The timetable for implementation varies according to the type of company, with stateowned enterprises required to comply by 2012 , listed companies by 2016 , and other companies by $2018 .^{360}$ If the quota is not met by 2017 , all departing directors in noncomplying companies are to be replaced by female directors. ${ }^{361}$ If noncompliance persists, the directors of companies that have not complied with this rule will lose their benefits. ${ }^{362}$ The effects of this rule have been limited so far, with the percentage of women on boards in Belgium increasing from $6.9 \%$ in 2009 to $9.2 \%$ in $2013 .{ }^{363}$

\section{France}

In France, the implementation of a compulsory gender quota for corporations was delayed by a constitutional challenge to the initially proposed legislation in $2006 .^{364}$ In January 2011, the quota passed after the constitution was amended in 2008 to include a requirement that all French law promote equal access to positions of "professional and social" responsibility. ${ }^{365}$ The quota was set at $40 \%$ with a compliance date of

359. See Loi modifiant la loi du 21 mars 1991 portant réforme de certaines enterprises publiques économiques, le Code des sociétés et la loi du 19 avril 2002 relative à la rationalisation du fonctionnement et de la gestion de la Loterie Nationale afin de garantir la présence des femmes dans le conseil d'administration des enterprises publiques autonomes, des sociétés cotées et de la Loterie Nationale [Law Modifying the Law of March 21, 1991 Reforming Certain Public Economic Enterprises, the Belgian Company Code and the Act of April 19, 2002 on the Rationalization of the Function and Management of a National Lottery to Ensure the Presence of Women on the Board of Autonomous Public Enterprises, Listed Companies, and the National Lottery] of June 16, 2011, Moniteur Belge [M.B.] [Official Gazette of Belgium], Sept. 14, 2011, 2d ed.

360. See id.

361. See id.

362. See id.

363. Kimberly Gladman \& Michelle Lamb, 2013 Women on Boards Survey, GMI RATINGS 1, 9 tbl.5 (2013), http://www.boarddiversity.ca/sites/default/files/GMIRatings_ WOB_042013.pdf.

364. Conseil constitutionnel [CC] [Constitutional Court] decision No. 2006-533DC, Mar. 30, 2006 (Fr.).

365. See Loi 2008-724 du 23 julliet 2008 de modernisation des institutions de la Ve République [Law 2008-724 of July 23, 2008 To Modernize the Institutions of the Fifth Republic], Journal OfFICIEL DE la RÉPuBliQue FranÇAise [J.O.] [OFFICIAL GaZETTE OF FRANCE], July 24, 2008, p. 11890. 
2017; there is an interim compliance requirement of $20 \%$ by 2014 and an immediate requirement that single-sex boards appoint at least one director of the opposite sex. ${ }^{366}$ Sanctions for noncompliance include the voiding of director nominations and suspension of directors' fees. ${ }^{367}$ This policy has seen the percentage of female directors increase from $9 \%$ in 2009 to $18.3 \%$ in $2013 .^{368}$

\section{Iceland}

After requiring that state-owned and municipal boards have gender parity in 2006, in March 2010 Iceland enacted a law requiring that public and private limited companies with fifty employees or more ensure that their corporate boards be comprised of a minimum of $40 \%$ of each gender. ${ }^{369}$ Although the compliance date was set at September 2013, compliance was reached by April 2013 with $48.9 \%$ of directors being female. $^{370}$

\section{India}

On December 18, 2012, as part of a series of measures designed to improve corporate governance, the Indian Companies Act was amended to require certain companies to have at least one female director within three years of listing. ${ }^{371}$ The Act passed the Rajya Sabha on August 8,

366. See Loi 2011-103 du 27 janvier 2011 relative à la représentation équilibrée des femmes et des hommes au sein des conseils d'administration et de surveillance et à l'égalité professionnelle [Law 2011-103 of January 27, 2011 on the Balanced Representation of Men and Women on Boards of Directors and Supervisory and Professional Equality], JouRnAl OfFICIEL DE LA RÉPUBLIQUe FrANÇAise [J.O.] [Official Gazette of France], Jan. 28, 2011, p. 1680.

367. See id.

368. Gladman \& Lamb, supra note 363, at 9 tbl.5.

369. See Act on Equal Status and Equal Rights of Women and Men No.10/2008, as Amended by Act No. 162/2010 and No. 126/2011, art. 15 (Ice.), http://eng.velfer darraduneyti.is/media/acrobat-enskar_sidur/Act-on-equal-status-and-equal-rights-of-womenand-men_no-10-2008.pdf; Act No. 138/1994 Respecting Private Limited Companies, as Amended up to 1 May 2011, art. 39 (Ice.), http://eng.atvinnuvegaraduneyti.is/laws-andregulations/nr/nr/7343; Act Respecting Public Limited Companies No. 2/1995, as Amended up to 1 may 2011, art. 63 (Ice.), http://eng.atvinnuvegaraduneyti.is/laws-andregulations $/ \mathrm{nr} / \mathrm{nr} / 7336$.

370. European COMM'N, Women ANd Men in LeAdership Positions IN THE European Union, 2013: A Review of the Situation and Recent Progress 6 fig.1 (2013) [hereinafter EuROPEAN COMM'N, WOMEN AND MEN IN LEADERSHIP], http:// ec.europa.eu/justice/gender-equality/files/gender_balance_decision_making/131011_women men_leadership_en.pdf.

37̄. See The Companies Act, 2013, No. 18, Acts of Parliament, 2013 (India); Deloitte, supra note 154, at 6. 
2013, and was given presidential assent on August 29, 2013. ${ }^{372}$ However, there are uncertainties about the class of companies to which the requirement applies. ${ }^{373}$

\section{Italy}

Italy's quota of $40 \%$ is due to be realized by 2015 , having been passed in July 2011. ${ }^{374}$ Noncompliant companies face a staged regime of sanctions, ${ }^{375}$ including fines of up to $€ 1$ million and nullification of board elections. ${ }^{376}$ Female representation was $3.6 \%$ in 2009 and rose to $8.2 \%$ in 2013. ${ }^{377}$

\section{Malaysia}

By 2016, all public and limited liability companies with more than 250 employees in Malaysia must have 30\% female directors and senior managers. ${ }^{378}$ This policy was announced in June 2011 as an expansion of the 2004 policy to increase female representation in government agencies. ${ }^{379}$

\section{The Netherlands}

Quotas in the Netherlands apply to nominations for board appointments as well as board composition. ${ }^{380}$ Since January 1, 2013, publicly traded

372. See Companies Bill Passed, Hindu (Aug. 8, 2013, 10:18 PM), http://www. thehindu.com/business/Industry/companies-bill-passed/article5003777.ece; Companies Bill Receives President's Assent, TIMES INDIA (Aug. 31, 2013, 12:23 PM), http://timesofindia. indiatimes.com/business/india-business/Companies-Bill-receives-Presidents-assent/articleshow/ 22181405.cms.

373. See PricewaterhouseCoOpers India, Companies Act, 2013: Key Highlights AND ANALYSIS 19 (2013), http://www.pwc.in/en_IN/in/assets/pdfs/publications/2013/companies -act-2013-key-highlights-and-analysis.pdf.

374. See Legge 12 luglio 2011, n. 120, in G.U. July 28, 2011, n. 174 (It.); DeloitTE, supra note 154 , at 23.

375. Sylvia Walby, European Parliament, Legal Instruments for Gender QUOTAS IN MANAGEMENT BOARDS: 2013, at 5, 10-11 (2013), http://www.europarl.europa. eu/RegData/etudes/workshop/join/2013/474413/IPOL-FEMM_AT\%282013\%29474413_EN.pdf; EUROPEAN COMM'N, WOMEN IN DECISION-MAKING, supra note 11, at 18.

376. See Legge 12 luglio 2011, n. 120, in G.U. July 28, 2011 , n. 174 (It.).

377. Gladman \& Lamb, supra note 363, at 9 tbl.5.

378. DELOITTE, supra note 154 , at 11 .

379. Id.

380. See Wet van 6 juni 2011 tot wijziging van boek 2 van het Burgerlijk Wetboek in verband met de aanpassing van regels over bestuur en toezicht in naamloze en besloten 
companies with more than 250 employees must have a minimum of $30 \%$ female board members. ${ }^{381}$ Legislation passed in June 2011 and will terminate on January $1,2016 .{ }^{382}$ Companies not able to comply with the requirement must include in their annual report an outline of the steps planned to ensure future compliance. ${ }^{383}$

\section{Turkey}

Companies listed on the Istanbul Stock Exchange must have at least one female member in their executive committee. ${ }^{384}$ If a company does not comply with this principle, reasons must be "made public in its 'report of compliance' with the corporate governance principles." 385

\section{United Arab Emirates}

The United Arab Emirates is potentially the most surprising country to initiate gender quotas. In December 2012, Prime Minister Sheikh Mohammed announced via Twitter, "We have also made a decision to make the representation of women, in all the boards of directors of companies and gov[ernment] entities, compulsory" and "[w]omen proved themselves in many workplaces \& today we want them to have a strong presence in decision-making positions in our institutions." 386 The announcement came shortly after the third Arab Women Leadership Forum, which was held November 19-20, 2012, and focused on board leadership and diversity. ${ }^{387}$

vennootschappen [Act of June 6, 2011 To Amend Book 2 of the Civil Code in Connection with the Adjustment to Rules on Management and Control in Public and Private Companies], Stb. 2011 (Neth.).

381. Id.

382. Id.

383. Id.

384. See Kurumsal Yönetim Ilkelerinin Belirlenmesine ve Uygalanmasina Ilișkin Tebliğ [Communiqué on Determination and Application of Corporate Governance Principles], Ser. IV, No. 57, T.C. Resmi GAZETE [Official Gazette of Turkey], Feb. 11 2012 (Turk.); Goran Selanec \& Linda SEnden, European COMM'N, Positive ACtion Measures to Ensure Full Equality in Practice between Men and Women, INCLUDING ON COMPANY BOARDS 220 (rev. ed. 2012), http://ec.europa.eu/justice/genderequality/files/gender_balance_decision_making/report_gender-balance_2012_en.pdf.

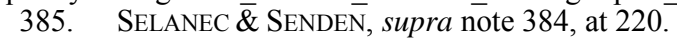

386. Sheikh Mohammed, TwITTER (Dec. 9, 2012, 3:36 AM), https://twitter.com/ hhshkmohd/status/277738509945679872; Sheikh Mohammed, TwITTER (Dec. 9, 2012, 3:37 AM), https://twitter.com/search?q=\%22women $\% 20$ proved $\% 20$ themselves $\% 20 \mathrm{in} \%$ 20 many\%20workplaces $\% 22 \&$ src $=$ typd.

387. See Noon, Dubai Women Establishment 7 (Jan. 2013), http://www.dwe.gov.ae/ data2/english third_noon.pdf. 


\section{H. Countries with Quotas for State-Owned Enterprises}

\section{Austria}

In 2008, Austria adopted a CGC that includes a recommendation that companies take gender representation into account when appointing directors to supervisory board. ${ }^{388}$ Following this, in March 2011, a quota was introduced for supervisory boards of companies with more than $50 \%$ state ownership. ${ }^{389}$ This quota requires that $35 \%$ of supervisory boards be female by 2018 , with an interim quota of $25 \%$ by $2013 .{ }^{390}$ This currently applies to fifty-five companies, of which forty-four are completely stateowned. $^{391}$ Although there are no formal sanctions, it has been suggested that sanctions would be instituted if widespread compliance is not seen. ${ }^{392}$

\section{Brazil}

In Brazil, Senate Bill 112 (2010) sets forth a program to increase female participation in companies with full or partial state ownership boards by $10 \%$ every two years until a rate of $40 \%$ is achieved by $2022 .{ }^{393}$ There are no sanctions associated with this program and implementation is as yet unmeasured. ${ }^{394}$

388. See AUSTRIAN WORKING GRP. FOR CORPORATE GOVERNANCE, supra note 144; Commission Staff Working Document: Annexes to the Impact Assessment on Costs and Benefits of Improving Gender Balance in the Boards of Companies Listed on Stock Exchanges Accompanying the Initiative To Improve Gender Balance in Company Boards, at 55, COM (2012) 614 final (Nov. 20, 2012) [hereinafter Commission Staff Working Document], http://www.eumonitor.nl/9353000/1/j9vvik7m1c3gyxp/vj4t79f5jjze\#p2.

389. Bernadette Allinger, Government Sets Female Quota for Board Representation, EUROFOUND (May 5, 2011), http://www.eurofound.europa.eu/eiro/2011/03/articles/at1103 011i.htm.

390. EUROPEAN WOMEN'S LOBBY, WOMEN ON BOARDS IN EUROPE FrOM A SNAIL'S Pace to a Giant Leap? EWL Report on Progress, Gaps, and Good Practice 7 (2012), http://www.womenlobby.org/publications/reports/article/women-on-boards-in-europe-from -a?lang=fr.

391. Allinger, supra note 389.

392. Id.

393. Isabel Afonso, Brazil, in Breaking the Glass CeIllng: Women IN THE BOARDROOM, supra note 98, at 34-35; Kellen Lazzaretti et. al., Gender Diversity in the Boards of Directors of Brazilian Businesses, 28 GENDER MGMT. 94, 98 (2013), http:// www.emeraldinsight.com/doi/full/10.1108/17542411311303239.

394. Afonso, supra note 393 , at 35 . 


\section{Canada}

The Canadian province of Quebec has taken steps to require that stateowned enterprises have gender parity on their boards. ${ }^{395}$ An act respecting the governance of state-owned enterprises and amending various legislative provisions was passed in December 2006 and compliance was required by December 2011. ${ }^{396}$

\section{Denmark}

The Danish Gender Equality Act-now part of the Consolidation Act on Gender Equality $2000^{397}$ —requires any company "where the expenses relating to the independent institution are mainly covered by government funds or where the state holds a majority interest of the company" to have at least $40 \%$ female board members. ${ }^{398}$ Relevant boards may be required to leave board seats vacant if they do not appoint a female. ${ }^{399}$

\section{Finland}

The Finnish government has stated its opposition to quotas on nongovernment boards, but in 2004 it introduced a requirement that stateowned enterprises have at least $40 \%$ female board members. ${ }^{400}$ This requirement had a very brief transition period and compliance was required by June 2005. ${ }^{401}$ An additional requirement for these companies, from which there are only limited exceptions permitted, is that at least one candidate of each gender be considered whenever a director's seat is vacant. $^{402}$

395. See Yetter, supra note 142, at 20-21.

396. Id.

397. Consolidation Act on Gender Equality, No. 1095, (Sept. 19, 2007), http://sm.dk/ en/files/bekendtgorelse-af-lov-om-ligestilling-af-kvinder-og-maend_en.pdf.

398. An Act to Consolidate the Law Relating to Gender Equality, INT'L LABOUR ORG., http://www.ilo.org/dyn/travail/docs/2051/Consolidation\%20Act\%20on\%20Gender\% 20Equality.pdf (last visited Mar. 30, 2015); accord Marianne Philip \& Kromann Reumert, Denmark, in Breaking the Glass CeILING: WOMEN In THE BoARdRoOM, supra note 98, at 71 .

399. See An Act to Consolidate the Law Relating to Gender Equality, supra note 398.

400. See European WOMEN's lOBBy, supra note 390, at 8; Fin. Ministry OF SOC. AfFAirs \& HeAlth, Gender Equality Pub. No. 2005:2, The ACT ON EQuality Between WOMEN AND MEN (2005), http://www.hsph.harvard.edu/population/womenrights/finland. women.05.pdf; Commission Staff Working Document, supra note 388, at 54.

401. Legislative Board Diversity, CATALYST, http://www.catalyst.org/legislativeboard-diversity (last visited Mar. 30, 2015).

402. Catalyst, InCREASING Gender Diversity on BoARds: CURRENT INDEX OF FORMAL APPROACHES 2 (rev. ed. 2012), http://www.womenandtechnology.eu/digitalcity/servlet/ 


\section{Greece}

Since September 2000, any Greek company that is partly or fully owned by the government has been subject to a one-third quota for stateappointed board seats. ${ }^{403}$ The Gender Equality Act also provides that noncompliant appointments, and even the decisions of noncompliant boards, are subject to annulment in court. ${ }^{404}$

\section{Ireland}

The boards of state-owned enterprises in Ireland have been subject to a $40 \%$ quota since $1995 .{ }^{405}$ This commitment is reiterated regularly as the opposition party asks for details of implementation in parliament, especially when individual companies fall below the quota. ${ }^{406}$ The National Women's Strategy 2007-2016 also reiterates the importance of this quota. ${ }^{407}$ Objective 14 of the strategy, "[t]o increase the number of women in decision-making positions in Ireland," is supported by actions 142-147, which deal with identification, training, nomination and appointment of women to state boards, and identification and training of women for private sector directorships. ${ }^{408}$

PublishedFileServlet/AAABYAHO/Approaches to Increasing_Gender_Diversity_on_B oards.pdf.

403. Commission Staff Working Document, supra note 388, at 55.

404. Id.

405. The European Commission reported that "[i]n 1995 the Irish Government introduced a requirement for a minimum of $40 \%$ of women and men appointed to all State boards." Jane Pillinger, Exchange of Good Practices on Gender Equality: Women in Economic Decision Making in Ireland 1 (2012), http://ec.europa.eu/justice/gender-equality/ files/exchange of good practice no/ie comments paper no 2012 en.pdf. However, despite being discussed in some forums as a quota, this requirement is more accurately described as a target. Indeed, despite having been in place since 1995, the target has not been met by some state boards. Dail Eireann (Mar. 11, 1992), http://debates.oireachtas.ie/dail/ 1992/03/11/00024.asp\#N97.

406. See, e.g., 760 DÁIL. DeB. col. 354 (Mar. 27, 2012) (Ir.).

407. See Gov't of Ir., National Women's Strategy 2007-2016 (2007), http:// justice.ie/en/JELR/National\%20Womens\%20Strategy\%20PDF.pdf/Files/National\%20W omens\%20Strategy\%20PDF.pdf.

408. Id. at $\mathrm{x}$. 


\section{Israel}

Gender equity in Israeli government companies has been successfully in place since 1993 when the Government Companies Law was amended to require "adequate representation" of both genders. ${ }^{409}$ Implementation was achieved by requiring that all appointments be from the underrepresented gender until the required quota was reached. ${ }^{410}$ Any firm in which the government holds more than half the voting rights is considered a government company. In 1994, the Israel Women's Network challenged the appointments of three mail directors, and the appointments were nullified by the High Court of Justice Israel. ${ }^{411}$ Despite the success of quotas on government boards, the Israeli government did not support a 2010 proposal to expand the quota to all companies. ${ }^{412}$

\section{Switzerland}

Switzerland has required that state-owned companies have at least $30 \%$ female directors since 2011, the result of legislation passed in $2006 .{ }^{413}$

\section{United Arab Emirates}

The requirement for United Arab Emirates companies to appoint women to their boards, which was announced by the Prime Minister via Twitter in December 2012, also applies to government boards. ${ }^{414}$

\section{Other Initiatives}

\section{Austria}

In 2008, Austria adopted a CGC that includes a recommendation that companies take gender representation into account when appointing directors to supervisory boards - not the management boards - and states that "the aspect of diversity of the supervisory board with respect to the representation of both genders and the age structure, and in the case of exchange-listed companies, also with a view to the internationality of the

409. Maharshak \& Wiesner, supra note 141, at 118.

410. Id.

411. See HCJ 453/94 Israel Women's Network v. Gov't, 48(5) [1984] (Isr.).

412. Maharshak \& Wiesner, supra note 141, at 119.

413. Urs Geiser, State Quota Offers Leg Up into Men's World, SWI (Jan. 23, 2014, 11:00 AM), http://www.swissinfo.ch/eng/state-quota-offers-leg-up-into-men-s-world/37 652042 .

414. See Sheikh Mohammed, TwiTTER (Dec. 9, 2012, 3:36 AM), https://twitter. com/hhshkmohd/status/277738509945679872. 
members" shall be given reasonable attention. ${ }^{415}$ This recommendation initially followed the pattern of comply or explain but was changed from C rule - comply or explain - to an L rule - legal - in 2012. ${ }^{416}$ Nevertheless, by January 2013 , only $13.5 \%$ of the supervisory boards of the top 200 Austrian companies were women. ${ }^{417}$

\section{Denmark}

Since April 2013, Denmark has required that state-owned enterprises with at least fifty employees, large publicly traded companies, and large private companies each set a target for increasing gender parity. ${ }^{418}$ This applies to over one thousand companies and is implemented by way of a "comply or explain" program. ${ }^{419}$ In addition, large companies must annually disclose their achievements in progressing towards their target and explain any failure to meet a target. ${ }^{420}$

\section{Finland}

A comply or explain regime instituted in January 2010 in Finland requires that all listed companies have at least one man and one woman on the board. ${ }^{421}$ By April 2013, women accounted for $29 \%$ of listed company board members, ${ }^{422}$ up from $9 \%$ in $2008 .{ }^{423}$

\section{Sweden}

Section 4.1 of the Swedish code of corporate governance states that the board should "exhibit diversity and breadth of qualifications, experience and background. The company is to strive for equal gender distribution

415. See AUSTRIAN WORKING GRP. FOR CORPORATE GOVERNANCE, supra note 144, at 33-34.

416. See id.; Sandra Mueller \& Bettina Knoetzl, Austria, in BrEaKING THE GLass CEILING: WOMEN IN THE BOARDROOM, supra note 98, at 65.

417. Id.

418. See Philip \& Reumert, supra note 398, at 71.

419. See id. at 70-71.

420. See id. at 72 .

421. Fin. Sec. Mkt. Ass'n, Finnish Corporate Governance Code 10 (2010), http://cgfinland.fi/files/2012/01/finnish-cg-code-2010.pdf; Nina Isokorpi \& Johanna Ellonen, Finland, in BREAKING THE GLASS CEILING: WOMEN IN THE BOARDROOM, supra note 98, at 74-75.

422. EUROPEAN COMM'N, WOMEN AND MEN In LEADERSHIP, supra note 370, at 6.

423. See EUROPEAN WoMEN's LoBby, supra note 390, at 8. 
on the board." ${ }^{24}$ Companies must report if the rule is not followed and provide an explanation of what action was taken. ${ }^{425}$ Quotas have been discussed but not set. ${ }^{426}$ The latest data suggest $27 \%$ of board seats are occupied by women, ${ }^{427}$ up from $22 \%$ in 2010 and $6 \%$ in $2002 .{ }^{428}$

\section{A BINDING SHAREHOLDER VOTE ON DIVERSITY}

Mandatory quotas, while superficially attractive because of their ability to achieve quick results, are likely to offer an inadequate solution to the problem of low representation of women on corporate boards in the long run. This is because, beyond mandating an outcome, they do little to address the complex systemic reasons for the lack of gender diversity at board level. Even more troubling is the generation of the wrong incentives for companies to appoint women solely for the purpose of satisfying a quota without adequate consideration of other reasons for choosing a particular candidate. Inevitably, as a result of the pursuit of such instrumental objectives, some less than ideal women candidates are likely to be appointed. Although such appointees may not be any worse than similarly placed men, the taint of appointment by quota might have negative consequences for both perception about merit in the short term and women's representation in the long term. By appointing token women candidates to satisfy quotas, companies will be able to claim advances in achieving gender equality despite not having undertaken more costly steps to develop the pipeline of top corporate executives. For all these reasons, quotas are a costly exercise in futility.

424. Swedish Corporate Governance Bd., The Swedish Corporate Governance CODE 17 (2010), http://www.corporategovernanceboard.se/media/45322/svenskkodbol agsstyrn_2010_eng_korrigerad20110321.pdf; see also Sara Mindus \& Ebba Werkell, Sweden, in BREAKING THE GLASS CEILING: WOMEN IN THE BOARDROOM, supra note 98, at 103 (quoting the same).

425. DELOITTE, supra note 154 , at 27.

426. See Lars Einar Engström, To Quota Or Not To Quota, That Is The Question, ON http://onthemarc.org/blogs/22/305\#.VIvJ1jGUf0Q;

Michael Nienaber, Germany To Introduce Legal Quotas for Women on Company Boards, REUTERS (Nov 25, 2014, 6:10 PM), http://www.reuters.com/article/2014/11/25/usgermany-women-quota-idUSKCN0J92JI20141125; New Swedish Government Mulls Quotas for Women on Company Boards, EuRAcTIV (Oct. 1, 2014, 9:01 AM), http://www.euractiv. com/sections/innovation-enterprise/new-swedish-government-mulls-quotas-women-companyboards-308834.

427. Mindus \& Werkell, supra note 424, at 103.

428. NORdic InVESTOR SERVS., AP2 IndEX OF FEMALE RePRESENTATION IN PUbliClyQuoted COMPANiEs: BoARds, EXeCuTIVE MANAGEMENTS AND EMPlOYEeS 6 (2014), http://www.ap2.se/Global/Kvinnoindex/NIS\%20AP2\%20Female\%20index\%202014_gb. pdf. 
We propose a model built upon the most oft-stated claim for greater gender diversity - that it is better for business. Crucially, we conceive of diversity being better for business in a sense larger than short-term profit maximization. Therefore, the generation of trust, credibility, and social representativeness might be worthy goals for corporations to pursue in their board appointments. As Justice Alito recognized in the recent U.S. Supreme Court decision in the Hobby Lobby case,

[e]ach American jurisdiction today either expressly or by implication authorizes corporations to be formed under its general corporation act for any lawful purpose or business. While it is certainly true that a central objective of for-profit corporations is to make money, modern corporate law does not require for-profit corporations to pursue profit at the expense of everything else, and many do not do so. For-profit corporations, with ownership approval, support a wide variety of charitable causes, and it is not at all uncommon for such corporations to further humanitarian and other altruistic objectives. 429

Justice Alito correctly characterized the purpose of the modern corporation, as evidenced by the conduct of business persons as being quite broad:

So long as its owners agree, a for-profit corporation may take costly pollutioncontrol and energy-conservation measures that go beyond what the law requires. A for-profit corporation that operates facilities in other countries may exceed the requirements of local law regarding working conditions and benefits. If for-profit corporations may pursue such worthy objectives, there is no apparent reason why they may not further religious objectives as well.430

Our model is built upon this broad conception of the firm by facilitating the appointment of directors so as to effectively pursue its goals in accordance with the desire of its shareholders. If having more women on the board is better for business, there is no better way to facilitate this than by empowering those who have the most to gain-the shareholders- to adopt measures in pursuit of this goal. Moreover, enforcement costs are low and the model is built upon decentralized monitoring and alternative sanctions. ${ }^{431}$ Our model is premised upon agency theory and the principalagent problem identified by scholarly literature. ${ }^{432}$ In the classic version of the principal-agent problem, because management has little of the

429. Burwell v. Hobby Lobby Stores, 134 S. Ct. 2751, 2770-71 (2014) (citations omitted).

430. Id. at 2771 (emphasis added).

431. See Sandeep Gopalan, Changing Social Norms on CEO Compensation: The Role of Norms Entreprenuers, 39 Rutgers L.J. 1 (2007).

432. See Michael C. Jensen \& William H. Meckling, Theory of the Firm: Managerial Behavior, Agency Costs and Ownership Structure, 3 J. FIN. ECON. 305 (1976). 
ownership of the firm at stake, there is the potential for them to take selfinterested actions at the expense of the owners - the shareholders. ${ }^{433}$ In the modern corporation with potentially millions of shareholders, the agency gap becomes acute because of collective action problems and rational apathy. At a structural level, incentives - monetary and nonmonetary - and monitoring can be designed to address the principal-agent gap. To be sure, shareholders have the greatest incentives to ensure mechanisms suited to the effective monitoring of management because they lose the most if management diverts firm resources to their own ends or performs poorly. Conversely, management has the most to lose by changing from path dependency and actively seeking out women for board appointments. Our proposal solves this problem of incongruence by mandating companies to offer shareholders a binding vote on (1) whether the company should consider diversity in board appointments and adopt a diversity policy, (2) if so, whether the company should impose a target quota, and (3) what steps should be taken to achieve the objectives of the policy. This vote would be held on an annual basis and companies would have an obligation to disclose the results publicly.

This model adopts existing models of shareholder empowerment in areas deemed to represent failures of corporate governance. Specifically, Australia, the United Kingdom, and the United States all have similar provisions on shareholder votes regarding CEO pay. ${ }^{434}$ These pieces of law could provide the architecture for our diversity-voting proposal, a brief outline of which is below.

\section{A. Australia}

The Australian model of shareholder voting on CEO pay was enacted in the Corporate Law Economic Reform Program (Audit Reform \& Corporate Disclosure) Act of 2004, or CLERP 9, which came into effect on July 1, 2004. ${ }^{435}$ Following dissatisfaction with the provisions, the Corporations Amendment (Improving Accountability on Director and Executive Remuneration) Act of 2011 was passed and entered into force in July $2011 .^{436}$ The key feature of the amendment is the invention of the two strikes rule, which requires companies to put a resolution for spilling the board if its remuneration report receives a vote of $25 \%$ or more at two

433. See id. at 308-09, 351.

434. See, e.g., Dodd-Frank Wall Street Reform and Consumer Protection Act, 15 U.S.C. $\S 78 n-1$ (2012).

435. Re-modelled CLERP 9 Lifts the Bar on Corporate Governance, DELOITTE (July 13, 2005), http://www.iasplus.com/en/binary/au/clerp9.pdf.

436. Corporations Amendment (Improving Accountability on Director and Executive Remuneration) Act 2011 (Cth) (Austl). 
consecutive annual general meetings (AGMs). ${ }^{437}$ The first strike is when the company's remuneration report receives a "no" vote of $25 \%$ or greater at an AGM. ${ }^{438}$ Then, the company has to explain in its next remuneration report whether it has taken note of shareholder concerns and what actions it has taken in response. ${ }^{439}$ If the board does not take any action, it must explain the reasons for such inaction. ${ }^{440}$

Section 250R of the Corporations Act is the key operative provision for a resolution for the adoption of the remuneration report; this must be put to a vote of the shareholders. ${ }^{44}$ The vote is purely advisory and not binding on the board of directors or the company. ${ }^{442}$ Key management personnel or related parties of such persons are not allowed to vote on this resolution if details of their compensation form part of the report. ${ }^{443}$ Section 300A provides the content of the matters to be disclosed as part of the remuneration report. ${ }^{444}$ This includes a "discussion of board policy" applicable for determining the compensation of the key management personnel of the company. ${ }^{445}$ Specifically, the report must contain a discussion of the link between the board policy on compensation and the firm's performance. ${ }^{446}$ If some compensation components are tied to the achievement of specific performance criteria, the report has to provide "a detailed summary of the performance condition" together with an explanation for the choice of that performance criterion. ${ }^{447}$ In addition, disclosure is required about both the justification for the methodology chosen for assessment and its details. ${ }^{448}$ In situations where performance is benchmarked against external factors, those details have to be disclosed, including the names of any companies or indices referenced. ${ }^{449}$ Disclosure is also mandated of components not related to performance along with an

437. Id. s 249L(2)(a)-(b).

438. Id. s 249L(2)(b).

439. Id. s 249L(2)(b)(i)-(ii).

440. Id. s $300 \mathrm{~A}(1)(\mathrm{g})(\mathrm{ii})$.

441. Corporations Act 2001 (Cth) s 250R(2), amended by Corporations Amendment Act 2011 (Cth) (Austl.).

442. Id. $\mathrm{s} 250 \mathrm{R}(3)$.

443. Id. $\mathrm{s} 250 \mathrm{R}(4)$.

444. Id. s 300A.

445. Id. s $300 \mathrm{~A}(1)(\mathrm{a})$.

446. Id. s $300 \mathrm{~A}(1)(\mathrm{b})$.

447. Id. s $300 \mathrm{~A}(1)(\mathrm{ba})(\mathrm{i})-(\mathrm{ii})$.

448. Id. s $300 \mathrm{~A}(1)$ (ba)(iii).

449. Id. s $300 \mathrm{~A}(1)(\mathrm{ba})(\mathrm{iv})$. 
explanation for the absence of the pay-performance link. ${ }^{450}$ Stock options awarded as part of the compensation mix have to be disclosed, including the value of options exercised during the year and the value of lapsed options. ${ }^{451}$ Other important elements include the length of employment contracts, termination notice periods, any termination payments payable, and details about remuneration consultants. ${ }^{452}$ Given that the objective is to ensure that CEO pay is closely correlated to firm performance, the provision requires discussion of the company's earnings and "the consequences of the company's performance on shareholder wealth" in that financial year and in the previous four financial years. ${ }^{453}$ This consequence on shareholder wealth is to be discussed in relation to matters such as dividends paid to shareholders during that year, changes in share price during that year, returns of capital to investors, and "any other relevant matter."

\section{B. The Dodd-Frank Say on Pay}

The Dodd-Frank Act was passed in 2010 in the aftermath of the financial crisis and unsurprisingly contained a provision on executive compensation. ${ }^{455}$ The relevant provision is section 951, which added Section 14A to the Securities Exchange Act of 1934 and mandated an advisory vote on executive compensation at least once every three years. ${ }^{456}$ Public companies are subject to the rule, and a vote on that frequency must be held at least once every six years "to determine whether votes on the resolutions required under paragraph (1) will occur every 1 , 2 , or 3 years." 457 In addition, companies are also required to hold a vote on golden parachute payments to executives in connection with "an acquisition, merger, consolidation, or proposed sale or other disposition of all or substantially all the assets of an issuer." 458 The SEC issued rules under the statute on January 25, 2011, and the final rules came into effect on April 4, 2011. ${ }^{459}$ Importantly, under section 951, the shareholder vote

450. Id. s $300 \mathrm{~A}(1)(\mathrm{d})$.

451. Id. s $300 \mathrm{~A}(1)(\mathrm{e})(\mathrm{ii})$-(iv).

452. Id. s $300 \mathrm{~A}(1)(\mathrm{e})(\mathrm{vii})$.

453. Id. s $300 \mathrm{~A}(1 \mathrm{AA})$.

454. Id. $\mathrm{s} 300 \mathrm{~A}(1 \mathrm{AB})$.

455. Dodd-Frank Wall Street Reform and Consumer Protection Act of 2010, Pub. L.

No. 111-203, 124 Stat. 1376 (2010) (codified in scattered sections of U.S.C.).

456. Id. § 951(a)(1), 124 Stat. at 1899 (codified at 15 U.S.C. $\S 78 n-1(a)(1)$ ).

457. Id. § 951(a)(2), 124 Stat. at 1899 (codified at 15 U.S.C. $\S 78 \mathrm{n}-1(\mathrm{a})(2)$ ).

458. Id. § 951(b)(1), 124 Stat. at 1899 (codified at 15 U.S.C. $§ 78 n-1(b)(1)$ ).

459. See Press Release, U.S. Sec. \& Exch. Comm'n, SEC Adopts Rules for Say-onPay and Golden Parachute Compensation as Required Under Dodd-Frank Act (Jan. 25, 2011), http://www.sec.gov/news/press/2011/2011-25.htm. 
may not be construed-(1) as overruling a decision by [the company] or board of directors; (2) to create or imply any change to the fiduciary duties of [the company] or board of directors; (3) to create or imply any additional fiduciary duties for [the company] or board of directors; or (4) to restrict or limit the ability of shareholders to make proposals for inclusion in proxy materials related to executive compensation. 460

Institutional investment managers subject to section 13(f) are required to provide an annual report on how they voted on say on pay resolutions. ${ }^{461}$

The early evidence on the impact of Dodd-Frank appears to be positive. Contrary to the calamitous projections of naysayers, most managementsponsored resolutions have been adopted and there is no evidence that companies have suffered in terms of attracting good executive talent. To the contrary, there is evidence of better engagement between management and shareholders, and it is likely that many conflicts are being averted by such engagement efforts. For instance, in 2014, say-on-pay resolutions received an average shareholder support of $93 \%$ based on a study conducted by the consulting firm Towers Watson. ${ }^{462}$ Scholarly work documents that “[p]oorly performing companies with high levels of executive pay often experienced greater shareholder dissatisfaction than other firms and made significant changes to their pay practices after unfavorable votes."463 The media and activists have also employed negative votes to shame executives seen to be greedy when their company has not performed to expectations. ${ }^{464}$ Although the evidence of constraining CEO pay might be thin, this shaming function is valuable in corporate law because of its expressive dimension and enabling of bargaining between shareholders and management.

\section{Merits of a Binding Vote on Diversity}

Our model has the following advantages over the legal approaches adopted by other jurisdictions considered above. First, it is consistent

460. Dodd-Frank Wall Street Reform and Consumer Protection Act of 2010, Pub. L. No. 111-203, § 951(c), 124 Stat. 1376, 1900 (2010) (codified at 15 U.S.C. § 78n-1(c)).

461. Id. § 951(d), 124 Stat. at 1900 (codified at 15 U.S.C. $\S 78 n-1(d)$ ).

462. Emily Chasan, Early Say-on-Pay Results Show Rising Support, Few Failures, WALl ST. J. (April 2, 2014, 4:22 PM), http://blogs.wsj.com/cfo/2014/04/02/early-say-onpay-results-show-rising-support-few-failures/.

463. Randall Thomas et al., Dodd-Frank's Say on Pay: Will It Lead to a Greater Role for Shareholders in Corporate Governance?, 97 CORNELL L. REV. 1213, 1216 (2012).

464. See Sandeep Gopalan, Shame Sanctions and Excessive CEO Pay, 32 DEL. J. CORP. L. 757, 758-59 (2007). 
with the agency theory of the firm and empowers shareholders to monitor management better to ensure that a "corporation[, which] is simply a form of organization used by human beings to achieve desired ends," actually delivers performance. ${ }^{465}$ To be sure, if, as the evidence indicates, women are better suited for board positions because of their detail orientation and propensity for intensive monitoring, management has an incentive to either block such appointments or at a minimum not to be proactive in seeking female candidates. Our proposal overcomes this principal-agent gap problem by allowing shareholders to determine whether the company should consider a diversity target.

Second, our model is not overly paternalistic and offers companies autonomy in designing optimal arrangements. Under the nexus of contracts theory of the firm, mandatory rules stipulated by the state are inferior because they stifle the ability of the market to craft superior solutions. If our model is adopted, the binding vote empowers shareholders and facilitates better engagement with management. As a result, there is likely to be bargaining between the two groups about whether the company would benefit from a diversity policy. Further, shareholders and management could negotiate a target quota that suits its unique situation in light of its business, product portfolio, target consumers, employee profile, and stakeholder relationships. As part of the bargaining, shareholders could also stipulate performance indicators for senior management such as a link between compensation and the achievement of the target quota. This would naturally vary from company to company and enable a level of experimentation and innovation that mandatory legislation cannot deliver. In turn, the operation of such performance measures and disclosure thereof would generate secondary effects such as the emergence of diversity champions and competitive positioning.

Third, our proposal is flexible and capable of variation more quickly than mandatory quota legislation. For instance, a company might achieve an optimal level of representation and decide that there is no need for a quota for the following year. It can assess whether gender diversity continues at that level or not and then decide on steps to address each situation. If diversity declines, it might tweak performance indicators and rewards for senior management rather than stipulating a quota. Or it might ask for development programs to generate a pipeline of senior executives capable of elevation over time. As is evident, there are innumerable permutations and combinations of available options for a company that cannot be specified in any legislative approach.

465. Burwell v. Hobby Lobby Stores, Inc., 134 S. Ct. 2751, 2768 (2014). 
Fourth, the proposal reduces the possibility of stigmatizing women who are appointed to boards because of perceptions about lack of merit. If women are appointed pursuant to a legislatively mandated quota, businesses will comply despite their objections and the women who are appointed will bear the cross of being diversity candidates. They are unlikely to feel the same sense of commitment to the board following negative attention. It is also likely that there will be conflict in the board because of resistance and antagonism by other members. In addition, such mandated quota appointments are likely to reduce shareholder and other constituencies' trust in the board due to a perception that board members have not been appointed because of competence but rather to satisfy a legal requirement. This is counterproductive to the asserted claims about diversity being good for business because the board expends its limited time on conflict and not on its primary function--monitoring the actions of management.

Fifth, the shareholder vote offers a public forum for discussion and debate about whether diversity appointments are suitable for the company reducing the potential for summary condemnation based purely upon the number of women on the board. If, after debate, there are bona fide reasons for not imposing a diversity policy, the company can escape stigma.

Finally, our proposal places responsibility in the hands of those with the most to gain from diversity within the limits of corporate governance law. Even under the narrow view of the corporate objective as shareholder wealth maximization, it stands to reason that the responsibility for taking steps that maximize wealth should rest with shareholders. The law's role is to remove any barriers, and the binding vote eliminates the problem of collective action and management capture.

\section{CONCLUSION}

There is a growing realization that the current low level of women's representation on corporate boards is difficult to justify in a society premised upon gender equality. Nevertheless, in the face of continued resistance by business interests to regulatory solutions, policy makers have focused upon offering business-friendly justifications for appointing more women directors claiming that increased representation is positively associated with firm performance. These arguments have been buttressed by a plethora of empirical studies examining the relationship between gender diversity and a variety of aspects of firm performance and purporting to show a positive relationship. Conversely, there are studies showing a negative association between diversity and firm performance highlighting 
increased conflict and decreased perceptions of merit. Both categories of empirical literature have problems of reverse causality and endogeneity, making clear conclusions difficult to draw. Amidst this landscape of empirical work, some of the clearest available evidence concerns the relationship between diversity and better monitoring of management. We argue that diversity goals will not be achieved by businesses absent regulatory action and that cheap talk is likely as long as information asymmetries persist. Therefore, we offer a model tailored to empowering shareholders and designed to enable one of the key structural goals of corporate governance law-to reduce the principal-agent gap via the mechanism of the board of directors. If shareholders have a say in the constitution of the board of directors and believe that diversity is an attribute worthy of pursuit, they can vote for it compelling management to consider more women for board positions. This solution is incentivecompatible, flexible, and less costly than mandatory quotas. 